\title{
A study protocol to prepare an RBD protein for vaccine
}

\section{against COVID-19 [version 1; peer review: 1 approved with}

\section{reservations, 1 not approved]}

\author{
ZMG Sarwar Jahangir (iD, Arleta Helena Marnik (iD) \\ Department of Biological Sciences, Kingsborough Community College of The City University of New York, Brooklyn, NY, 11235, USA
}

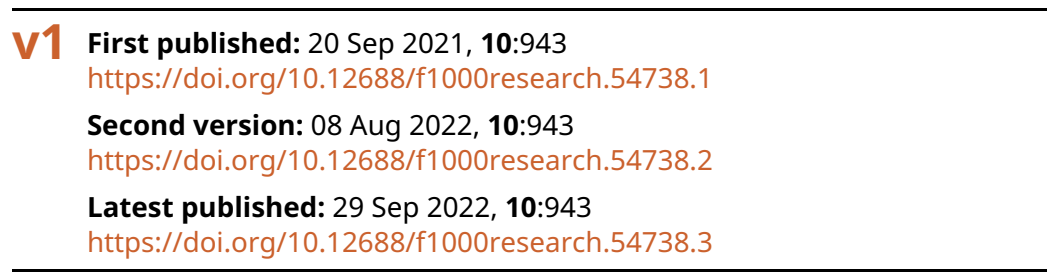

\section{Abstract}

Background: The SARS-CoV-2 pandemic is a global threat to humans and the world's economy. Effective and safe vaccines against this virus are essential to control and eradicate the pandemic. The currently applied vaccines carry SARS-CoV-2 spike-protein mRNA/cDNA. These vaccines go through several cellular processes in the recipients for producing antigens. On the contrary, the SARS-CoV-2 RBD (receptor binding domain)-protein is an antigen. It will directly stimulate antibody production against SARS-CoV-2. Hence, we propose to produce SARS-CoV-2 RBD-protein as a fast acting, effective and safe vaccine.

Methods: We propose to reconstruct a plasmid carrying three types of DNA sequences: RBD cDNA, FP (fusion peptide) DNA and sfGFP(superfolder green fluorescent protein), cDNA creating the RBDFP-sfGFP DNA within an orf (open reading frame). Escherichia coli, $\mathrm{C} 2566 \mathrm{H}$, transformed with the reconstructed plasmid will express RBD-FP-sfGFP fusion protein producing green fluorescent $c f u$ (colony forming unit). The RBD-protein will be separated from the sfGFP using an FP specific enterokinase, and eluted by HIC (hydrophobic interaction chromatography), detected with a BioVision Elisa kit, and quantified by spectrophotometry at UV280 ${ }_{\mathrm{nm}}$.

Results: The plasmid reconstruct will carry $\mathrm{amp}^{\mathrm{r}}$ (ampicillinresistant) gene as a selective marker and a T7 promoter controlling the expression of RBD-FP-sfGFP fusion protein. The transformed Escherichia coli will efficiently express the RBD-FP-sfGFP fusion protein. The highly efficient sfGFP fused within the RBD-FP-sfGFP will produce green fluorescent $c f u$. The RBD-FP-sfGFP protein extract from the green $c f u$, digested by enterokinase and separated by the HIC will produce pure RBD protein.

Conclusion: A positive BioVision ELISA test detects $<10$ pg RBD

protein $/ \mathrm{ml}$ of the sample. A larger sample of the purified RBD protein

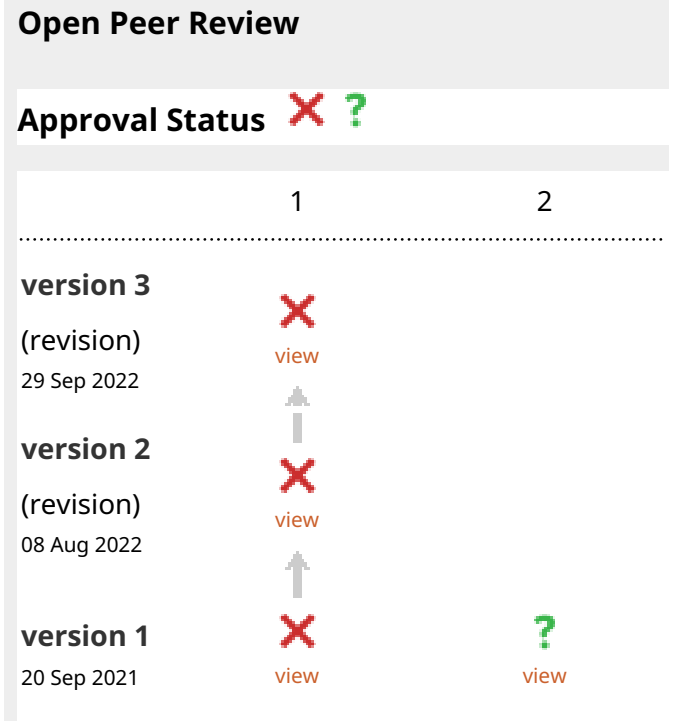

1. Wen-Hsiang Chen, Baylor College of Medicine, Houston, USA

2. A. H. M. Nurun Nabi (D), University of Dhaka, Dhaka, Bangladesh

Any reports and responses or comments on the article can be found at the end of the article. 
can be used as a vaccine following a standard formulation and safety protocols. Once administered, the RBD protein will stimulate antibody production against the SARS-CoV-2 virus. The RBD protein has no potential to recombine with human genome.

\section{Keywords}

receptor angiotensin-converting enzyme 2 , amino acids, colony forming unit, hydrophobic interaction chromatography, Luria Bertani microbial culture medium containing ampicillin, fusion peptide, open reading frame, receptor binding protein, Spike protein, severe respiratory syndrome coronavirus 2 , superfolder green fluorescent protein.

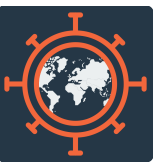

This article is included in the Emerging Diseases

and Outbreaks gateway.

\section{Corresponding author: ZMG Sarwar Jahangir (Hindal@msn.com)}

Author roles: Jahangir ZS: Conceptualization, Data Curation, Formal Analysis, Methodology, Project Administration, Resources, Supervision, Validation, Writing - Original Draft Preparation, Writing - Review \& Editing; Marnik AH: Data Curation, Investigation, Methodology, Resources, Validation, Writing - Original Draft Preparation, Writing - Review \& Editing

Competing interests: No competing interests were disclosed.

Grant information: The author(s) declared that no grants were involved in supporting this work.

Copyright: $\odot 2021$ Jahangir ZS and Marnik AH. This is an open access article distributed under the terms of the Creative Commons Attribution License, which permits unrestricted use, distribution, and reproduction in any medium, provided the original work is properly cited.

How to cite this article: Jahangir ZS and Marnik AH. A study protocol to prepare an RBD protein for vaccine against COVID-19 [version 1; peer review: 1 approved with reservations, 1 not approved] F1000Research 2021, 10:943

https://doi.org/10.12688/f1000research.54738.1

First published: 20 Sep 2021, 10:943 https://doi.org/10.12688/f1000research.54738.1 


\section{Introduction}

\section{A brief history of coronavirus infection}

Using the "RNA-Dependent RNA Polymerase Molecular Clock", it was estimated that the common ancestor of coronavirus $(\mathrm{CoV})$ appeared about 10,000 years ago., ${ }^{2,3}$ The first human upper respiratory tract infection (URTI) caused by human $\mathrm{CoV}$ (H-CoV) was reported in $1965 .^{4-7}$ The first severe acute respiratory syndrome caused by CoV (SARS$\mathrm{CoV}$ ) was reported from Guangdong, China, in 2002, that ultimately spread over many countries causing an epidemic in the Americas, Europe, and Asia, infecting over 8,098 people and killing about 774 of the infected. ${ }^{6,8}$ SARS-CoV has 99.6\% genome sequence homology to CoV found in masked palm civets (Paguma larvata) and 88\% - 95\% homology to $\mathrm{CoV}$ found in several horseshoe bats, Rhinolophus pussilius, $R$. macrotis, R. pearsoni and $R$. sinicus. ${ }^{9-11}$

This was followed by another outbreak of a CoV epidemic in 2012 that started in Saudi Arabia, which is known as Middle East respiratory syndrome (MERS) and is caused by MERS-CoV. ${ }^{12,13}$ It spread over 27 countries, reaching Western Africa to the west and South Korea to the east, infecting over 2,400 and killing over 850 people. ${ }^{12,13}$ The $^{2}$ survivors suffered from many diseases including heart, kidney, and multiorgan failures. ${ }^{12,14,15}$ In November 2019 , another CoV epidemic emerged in Wuhan, China, found to be caused by SARS-CoV-2 infections, leading to a global pandemic. That epidemic infected over 179 million people and killed over 3.8 million as of June $2021 .{ }^{16}$

Coronavirus infections are not a new challenge to human survival. Some of those challenges, we know, others are unknown to us. However, it is clear that the recent pandemic of 2019 will not be the last, and we have to be alert and keep us ready to be safe for the future.

\section{The benefits and importance of SARS-CoV-2 vaccines}

All types of viruses mutate and evolve as they replicate. Their prolonged presence in an uncontrolled environment favors development of new variants. That ability to generate de novo diversity in a short period of time, as well as the rate of spontaneous mutation, vary among viruses. Furthermore, mutation rates in RNA viruses are higher than DNA viruses, and are higher in single-stranded viruses than double-stranded viruses. ${ }^{17}$

Hence, vaccinating a smaller segment of a population against SARS-CoV-2 may favor generation of new variants with new infectivity. In that scenario, even the vaccinated individuals would face risks from arrivals of new variants. This may only be brought under control by administering a safe and effective vaccine as soon as possible to a significantly large part of the population. Successes of such efforts will reduce the development of new variants and, thus, help the global human population attain herd immunity. ${ }^{18}$

As cases of coronavirus disease 2019 (COVID-19) were growing globally, it brought together the efforts of worldwide biotechnologists, scientists, experts, pharmaceuticals, and investors to develop effective vaccines against SARS-CoV-2 as soon as possible. More than 50 such vaccine candidates were put into human trials in 2020, and a total of 250 vaccine candidates were in the process of being developed. ${ }^{19}$ The safety and effectiveness of a vaccine are measured by the vaccine's long-term antigenicity and immunogenicity for its therapeutic application as a vaccine. However, we still do not have direct evidence of the long-term efficacy of the short life mRNA and long-life cDNA antigenic vaccines.

SARS-CoV-2 mutates at a rate four times slower than the influenza virus, and the new variants have a minimal effect on antigenicity of the virus. ${ }^{20,21}$ Although the coronaviruses mutate at a slower rate, some of the new variants of SARSCoV-2, such as D $614 \mathrm{G}$, that mutated outside the receptor-binding domain (RBD) residue have a higher rate of infectivity by boosting viral replication in lung and respiratory tract tissues. ${ }^{22,23}$ This suggests that the RBD residue is more conserved and, hence, the RBD protein vaccines will be effective against multiple SARS-CoV-2 variants.

\section{Advantages for using the RBD protein vaccine}

The RBD is a small segment of the spike protein (S-protein) located on the outer membrane of the SARS-CoV-2 virion. It plays a critical role in binding the virus to the angiotensin-converting enzyme 2 (ACE-2) receptors on human mucosal cells, causing infection leading to COVID-19. Hence, an antibody generated against the RBD protein will be able to strongly prevent any SARS-CoV-2 infection.

According to Huang, et al., ${ }^{24}$ the S-protein located on the SARS-CoV-2 virus envelope is composed of 1273 amino acids (aa). The S-protein consists of a 13 aa long signal peptide (1-13 residues), followed by a 672 aa long S1 domain (14-685 residues), and a 588 aa long S2 domain (686-1273 residues). The S1 domain contains a 292 aa long N-terminal domain (14-305 residues) and a 223 aa long RBD domain (319-541 residues). The SARS-CoV-2 encapsulating membrane holds many trimeric S-proteins, each containing three RBD protein monomers, that binds to the ACE-2 receptors present in human cells. ${ }^{25}$ Furthermore, Yang, et al., ${ }^{26}$ also demonstrated that the S1 domain of the SARS-CoV-2 spike protein 
directly binds to ACE-2 receptors expressed by the undifferentiated human alveolar cells (A549) facilitating the entry of SARS-CoV-2 into these cells. It was also reported that the SARS-CoV-2 receptor-blocking human antibody, HA001, attaches to amino acid residues A475 and F486 in the RBD of the SARS-CoV-2 spike protein. ${ }^{27}$ In this process, a 71 aa long segment of the RBD, known as receptor binding motif (RBM), tightly binds to the ACE- 2 receptor. ${ }^{28}$ Furthermore, the RBD contains nine cysteine (Cys) residues making four pairs and keeping one free Cys. The three pairs are Cys336Cys361, Cys379-Cys432, and Cys391-Cys525 residues that form the core RBD $\beta$ sheet related to its 3D structure. The remaining pair, Cys480-Cys488 residue, binds to the N-terminal peptidase domain of ACE- $2 .{ }^{29}$ All the above information supports that the RBD protein will be a highly effective antigen for vaccine production against SARS-CoV-2.

\section{Our proposal}

We propose to reconstruct an $a m p^{r}$ plasmid expression vector carrying RBD and superfolder green fluorescent protein (sfGFP) cDNAs linked by an oligo DNA, coding for a fusion peptide (FP), Asp-Asp-Asp-Asp-Lys. ${ }^{1}$ The construct will be expressed using Escherichia coli, $\mathrm{C} 2566 \mathrm{H}$, producing the RBD-FP-sfGFP fusion protein. The RBD protein will be separated from the RBD-FP-sfGFP fusion protein by digestion with an enterokinase (specific for the FP) and isolated by hydrophobic interaction chromatography (HIC). The RBD eluate will be analyzed to determine its size by SDS-PAGE (sodium dodecyl sulfate-polyacrylamide gel electrophoresis), tested for its immuno-reactivity with SARS-CoV-2 S-protein antibody using a BioVision ELISA kit, and quantified by spectrophotometry. The purified RBD protein will be available to study its efficacy following approved vaccine formulation and clinical trials.

\section{Proposed methods}

This study protocol is a meticulously derived scientific procedure without involving any test animals or test subjects. Hence, it does not require ethical approval at this time. Any further information on this matter, may be obtained from the "Institutional Review Board" (IRB). Once we are ready to submit a grant application and execution of the protocol, we will seek the IRB approval in due course.

\section{Specialized reagents and materials}

The following specialized reagents and materials (from the same or alternate sources) will be required in addition to regular materials and reagents available in a running biotechnology laboratory.

1. RBD cDNA: Addgene plasmid, Cat \#141184, pcDNA3-SARS-CoV-2-S-RBD-sfGFP (Amp ${ }^{\mathrm{R}}, \mathrm{Neo}^{\mathrm{R}} / \mathrm{Kan}^{\mathrm{R}}$ ).

2. Prokaryotic host cells: Escherichia coli, NEB, Cat \# C2566H.

3. Plasmid DNA extraction kit: Promega PureYield Plasmid Miniprep System I and a Protocol. Promega, Cat \# A1222, and Promega Technical Bulletin \# TB374.

4. Custom made linker oligo DNA coding for the FP to be used for plasmid recombination: It is a double-stranded linker oligo DNA with ss (single-stranded) $5^{\prime}$ overhangs. This will contain a forward strand, $5^{\prime}$ GATCGGAT GATGATGATAAAC $3^{\prime}$, and a reverse strand, $3^{\prime}$ CCTACTACTACTATTTGCTAG $5^{\prime}$, each carrying a ss $5^{\prime}$ GATC $3^{\prime}$ overhang at the $5^{\prime}$ end, Figure 1 , to be obtained from GenScript, NJ. The working concentration will be adjusted to $10^{5}$ units in $1 \mu \mathrm{l}$.

5. A chromatography kit: Green Fluorescent Protein Chromatography Kit, Bio-Rad, Cat \# 1660005EDU. It is a HIC (hydrophobic interaction chromatography) kit.

6. Protein dialysis tubing: SnakeSkin dialysis tubing with $10 \mathrm{kDa}$ molecular weight cut-off, Thermo Fisher Scientific, Cat \# 88243.

\section{5 'GATCGGATGATGATGATAAAC3' 3' CCTACTACTACTATTTGCTAG 5'}

Figure 1. Oligo DNA insert. A 17 bp (base pair) double-stranded DNA with 4 bases long single-stranded (ss) overhangs at the $5^{\prime}$ ends. Forward strand, $5^{\prime}$ GATCGGATGATGATGATAAAC $3^{\prime}$ and the reverse strand, $3^{\prime}$ CCTACTAC TACTATTTGCTAG 5', each carrying a ss (single stranded) $5^{\prime}$ GATC overhang. 
7. Power supply unit: Invitrogen PowerEase Touch 600W Power Supply. Thermo Fisher Scientific, Cat \# PS0601.

8. Electrophoretic unit: Mini Gel Tank, Thermo Fisher Scientific, Cat \# A25977.

9. Protein electrophoresis gel slabs: NuPAGE 4-12\%, Bis-Tris, $1 \mathrm{~mm}, 12$-well mini protein gradient gel. Thermo Fisher Scientific, Cat \# NP0322PK2.

10. Protein sample buffer: NuPAGE LDS Sample Buffer (4×), Thermo Fisher Scientific, Cat \# NP0007.

11. Protein electrophoresis buffer: NuPAGE MES SDS Running Buffer $(20 \times)$, Thermo Fisher Scientific, Cat \# NP0002.

12. Protein standard: Unstained Protein Standard, Broad Range (10-200 kDa) (NEB \#P7717).

13. Immunodetection kit: ELISA Kit, BioVision, Cat \# E4877.

14. Culture media and other reagents: LB (Luria-Bertini)-agar and LB broth, and SOC (Super Optimal broth with Catabolite repression medium) bacterial cell culture media; Isopropyl- $\beta$-D-1-thiogalactopyranoside (IPTG), from Thermo Fisher Scientific or NEB.

15. Enzymes: BamHI (NEB, Cat \# R3136S); Enterokinase (NEB, Cat \#P8070); Enterokinase removal kit (SigmaAldrich, Cat \# PRKE); Lysozyme solution (Millipore-Sigma, Cat \# L3790); Proteinase K, 800 u/ml (NEB, Cat \# P8107S); T4 DNA Ligase (NEB, M0202).

16. Tris-EDTA (TE) Buffer (20×, pH 9.2): Composed of $0.2 \mathrm{M}$ Tris- $\mathrm{HCl}$ and $20 \mathrm{mM}$ EDTA, $\mathrm{pH} 7.5$ at $25^{\circ} \mathrm{C}$, Promega, Cat \# A2651; pH to be adjusted to 9.2 by adding $0.1 \mathrm{M} \mathrm{NaOH}$.

17. Tris-buffer containing $20 \mathrm{mM}$ Tris, $200 \mathrm{mM} \mathrm{NaCl,pH} \mathrm{8.0,} \mathrm{Sigma-Aldrich,} \mathrm{Cat} \mathrm{\#} 93283$.

18. Protein stain: InstantBlue stain, 1 L, VWR, Cat \# 95045-070. It is a Coomassie blue protein stain, ready to use for SDS-PAGE.

Bellow, we provide a unique study protocol for the production of SARS-CoV-2 RBD protein antigen using recombinant DNA technology. The RBD protein thus produced can be used as a COVID-19 vaccine after formulation, and evaluation for clinical efficacy and safety.

Replication and purification of the plasmid carrying RBD-sfGFP cDNAs

A sample of Escherichia coli from a stock carrying the Addgene plasmid, Cat $\# 141184$, will be grown overnight at $37^{\circ} \mathrm{C}$ in $10 \mathrm{ml} \mathrm{LB}$-ampicillin broth. The plasmid DNA will be isolated from the cells using PureYield Plasmid Miniprep System I (Promega, Cat \#A1222 and a Technical Bulletin \#TB374). The purity of the plasmid DNA will be determined by the UV $\mathrm{OD}_{260 \mathrm{~nm}} / \mathrm{OD}_{280 \mathrm{~nm}}(\mathrm{OD}=$ optical density) absorption ratio. A ratio of $\geq 1.8$ is generally accepted as a value for "pure" DNA. ${ }^{30}$ If the ratio is $<1.8$, we will add $0.1 \mu \mathrm{l}(0.8$ units) Proteinase $\mathrm{K}$ to the sample, incubate it at room temperature for 15 minutes, add two volumes of ice-cold $95 \%$ ethanol, mix well, centrifuge at $10,000 \mathrm{~g}$ at $4{ }^{\circ} \mathrm{C}$ for five minutes, pour off the supernatant, bring the DNA into solution in TE, and determine the purity of the DNA following its $\mathrm{OD}_{260 \mathrm{~nm}} / \mathrm{OD}_{280 \mathrm{~nm}}$ absorption ratio. The plasmid DNA concentration will be equal to, $\mathrm{OD}_{260 \mathrm{~nm}} \times$ the dilution factor $\times 50=\mu \mathrm{g}$ plasmid $\mathrm{DNA} / \mathrm{ml}$.

Plasmid reconstruction with modification

Linearizing the plasmid. The plasmid in solution will be digested with Bam $\mathrm{HI}$ in Bam $\mathrm{HI}$ buffer at $37^{\circ} \mathrm{C}$ for 2 hours, heat denatured at $65^{\circ} \mathrm{C}$ for one minute, and chilled at $4{ }^{\circ} \mathrm{C}$ for 10 minutes. Then, two volumes of ice-cold $95 \%$ ethanol will be added into it, mixed well, chilled for 10 minutes at $-20^{\circ} \mathrm{C}$, and centrifuged at $10,000 \mathrm{~g}$ using a Sorvall SS34 Fixed Angle Rotor, at $4^{\circ} \mathrm{C}$ for five minutes. The supernatant containing the linearized plasmid will be transferred into a fresh microfuge tube. The linearized plasmid will carry the RBD cDNA at one end and the sfGFP cDNA at the other end, as shown in Figure 2. 


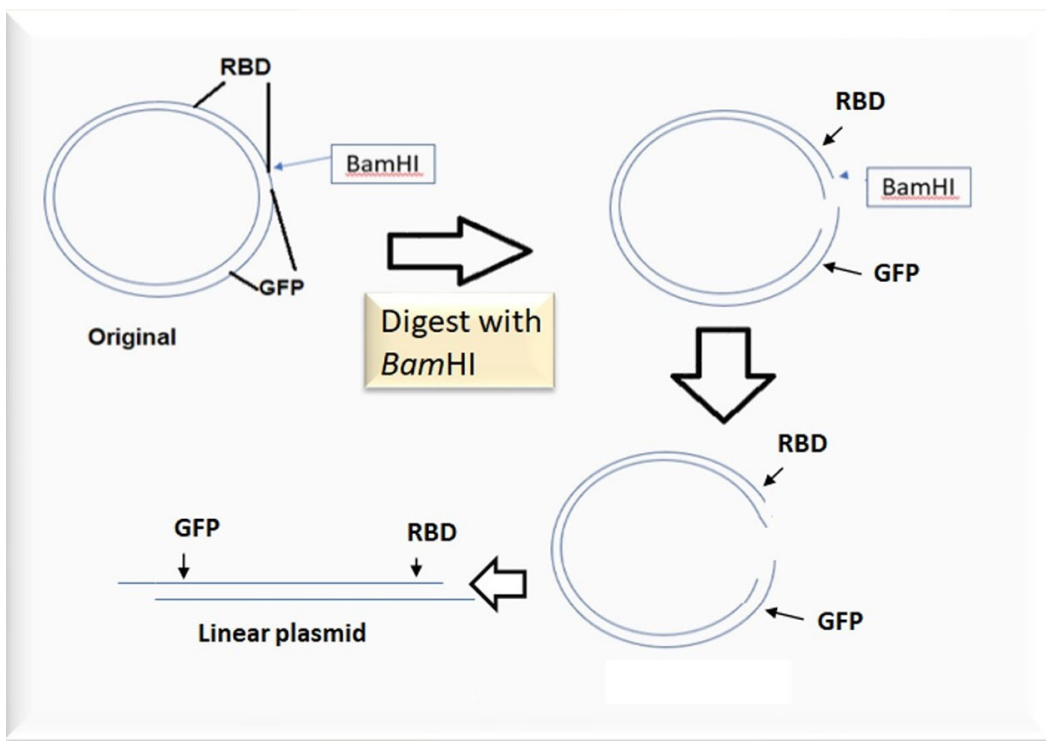

Figure 2. Addgene plasmid, 141184, linearization using BamHI restriction enzyme.

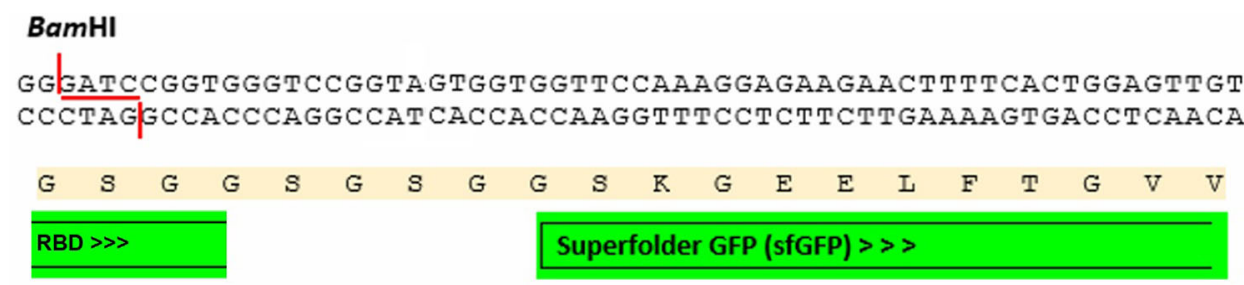

Figure 3. An excerpt from Addgene, 141184, showing the BamHI site located terminally at the RBD cDNA followed by the sfGFP cDNA.

Ligating covalently the linker oligo DNA (FP-DNA) into the linearized plasmid. We will add $1 \mu \mathrm{l}$ of the linker oligo to the linearized plasmid in the microfuge tube. Then, we will add $1 \mu \mathrm{l} 4 \mathrm{DNA}$ (NEB, M0202) ligase containing $400-$ 500 units in $1 \times \mathrm{T} 4 \mathrm{DNA}$ ligase buffer, incubate at $16^{\circ} \mathrm{C}$ for 2 hours, deactivate the ligase by heating at $65^{\circ} \mathrm{C}$ for 10 minutes, chill at $4^{\circ} \mathrm{C}$ for five minutes, add two volumes of ice-cold $95 \%$ ethanol, mix well, and centrifuge at $10,000 \mathrm{~g}$ at $4^{\circ} \mathrm{C}$ for five minutes. The supernatant containing the ligated plasmid will be transferred into a fresh microfuge tube and the purity of the plasmid DNA will be determined following UV absorption ratio at $\mathrm{OD}_{260 \mathrm{~nm}} / \mathrm{OD}_{280 \mathrm{~nm}}$ reaching $\geq 1$. 8 . If the ratio is $<1.8$, add $0.1 \mu \mathrm{l}$ ( 0.8 units) Proteinase K, incubate at room temperature for 15 minutes, add two volumes of icecold $95 \%$ ethanol, mix well, centrifuge at $10,000 \mathrm{~g}$ at $4^{\circ} \mathrm{C}$ for five minutes, pour off the supernatant, bring the DNA into solution in TE, and then again determine the purity of the DNA following its $\mathrm{OD}_{260 \mathrm{~nm}} / \mathrm{OD}_{280 \mathrm{~nm}}$ absorption ratio. The plasmid DNA concentration will be equal to: $\mathrm{OD}_{260 \mathrm{~nm}} \times$ the dilution factor $\times 50$ in $\mu \mathrm{g}$ plasmid DNA/ml.

The incorporation of the oligo DNA (Figure 1), into the plasmid (Addgene, 141184) will be accomplished following a standard protocol for plasmid linearization, insertion of the oligo DNA, and ligation using T4 DNA ligase. The insertion of the oligo DNA will take place at the BamHI site located terminally at the RBD cDNA, and 21 bp upstream to the sfGFP cDNA as in Figure 3.

The oligo DNA insert will code for a heptapeptide, DDDDKRS, fused in-between the RBD-sfGFP fusion protein, coding for a novel RBD-FP-sfGFP fusion protein (Figure 4).

\begin{tabular}{|c|c|c|}
\hline & Original translated & Recombined translated \\
\hline Protein sequence & RBD $\Rightarrow \stackrel{\text { GSGGSGSGGSKGEELFTGVV }}{\Rightarrow} \underset{\text { sfGFP }}{\Rightarrow}$ & RBD $\Rightarrow \stackrel{\text { GSDDDDKRSGGSGSGGSKGEELFTGVV }}{\Rightarrow \text { sfGFP }}$ \\
\hline
\end{tabular}

Figure 4. A comparison of the "original translated" RBD-sfGFP fusion protein with the "recombined translated" RBD-FP (underlined) -sfGFP fusion protein. The fusion peptide, DDDDKRS (underlined), is shown in the "Recombined translated", RBD-FP (underlined) -sfGFP fusion protein produced by the recombined plasmid. 


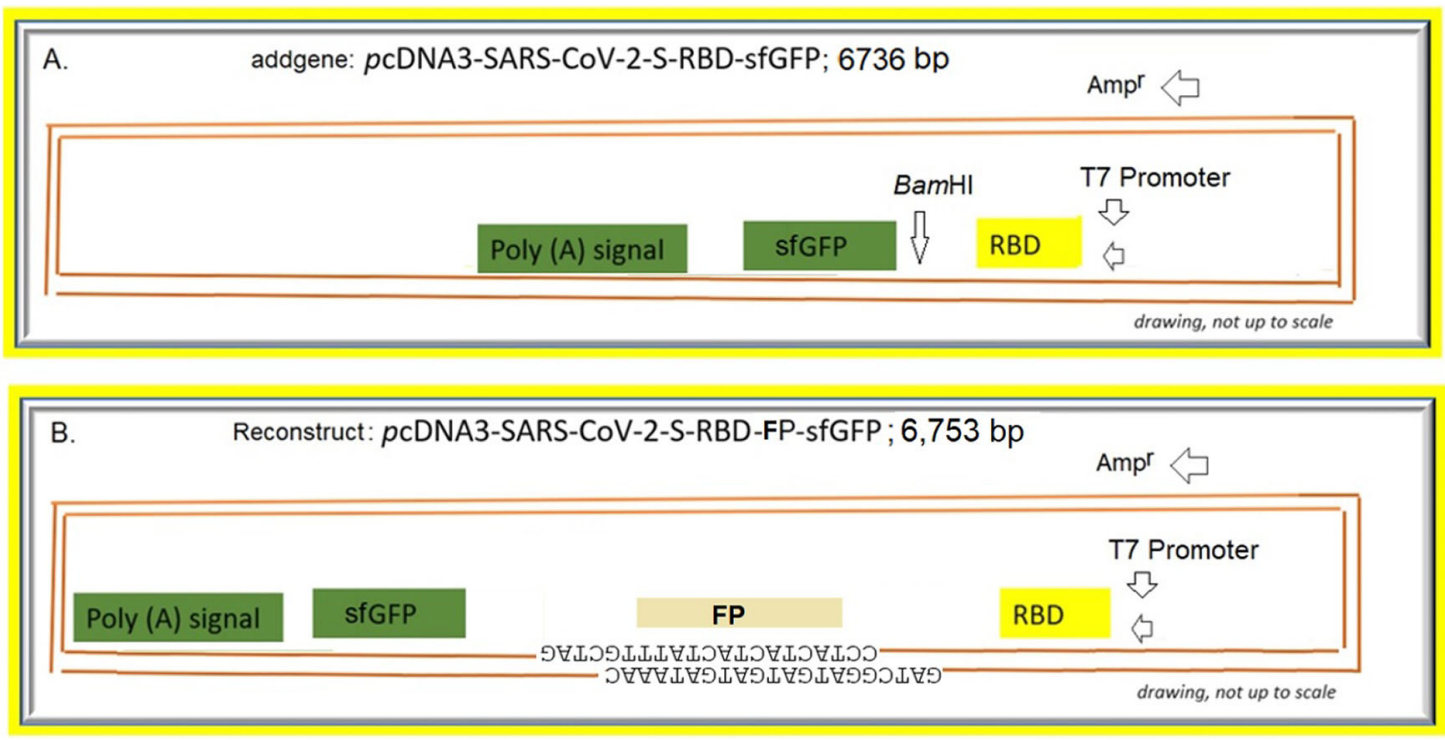

Figure 5. (A) The original Addgene plasmid, 141184, carrying pcDNA3-SARS-CoV-2-S-RBD-sfGFP, 6736 bp (base pair). (B) The reconstructed plasmid carrying RBD cDNA-FP oligo DNA-sfGFP CDNA, 6753 bp. The fusion peptide (FP) carrying a 17 bp long ds oligo, with 4 bases long ss 5' GATC BamHI linker DNA sequence at either ends.

The original plasmid carries RBD cDNA-sfGFP cDNA is shown in Figure 5A, and the ligated plasmid reconstruct will carry the RBD cDNA-FP DNA-sfGFP cDNA linked in order within one orf, as shown in Figure 5B.

Transformation and growing Escherichia coli, $\mathrm{C} 2566 \mathrm{H}$, with the reconstructed plasmid The Escherichia coli, $\mathrm{C} 2566 \mathrm{H}$, carrying T7 RNA polymerase gene will be used as a host. The host, transformed with the recombined plasmid, will express the orf producing RBD-FP-sfGFP fusion protein.

Transformation. We will thaw a sample of competent Escherichia coli, $\mathrm{C} 2566 \mathrm{H}$, cells for 10 minutes in ice at $4^{\circ} \mathrm{C}$, mix well gently, pipette out $50 \mu \mathrm{l}$ of the cells in suspension into an ice-cold fresh $1.5 \mathrm{ml}$ microfuge tube in ice, add $100 \mathrm{pg}$ reconstructed plasmid DNA, mix well gently without vortexing, chill the microfuge tube in ice for 30 minutes, place the microfuge tube into a Styrofoam holder, transfer the holder into a $42^{\circ} \mathrm{C}$ water bath, wait for 15 seconds, take out the microfuge tube, and chill it in ice for five minutes without mixing.

Then, we will add $950 \mu \mathrm{l} \mathrm{SOC},{ }^{31}$ maintained at room temperature, into the microfuge tube containing the transformed cells, incubate at $37^{\circ} \mathrm{C}$ for 60 minutes, and shake vigorously while under incubation using a rotator. This will complete the transformation process.

Plating the transformed Escherichia coli. We will warm up prepared petri dishes/plates $(100 \mathrm{~mm} \times 15 \mathrm{~mm})$ containing $20 \mathrm{ml} \mathrm{LB}-A m p-A g a r(1.5 \%)$ at room temperature for 15 minutes. Using a sterile pipette, we will add aseptically $250 \mu 1$ SOC medium containing the transformed $E$. coli cells into the petri dish and add $80 \mu$ filter sterilized $100 \mathrm{mM}$ IPTG solution into the dish over the SOC medium. Then, we will spread the SOC medium with the transformed cells evenly over the agar throughout the dish/plate with a sterilized spreader and incubate it overnight at $37^{\circ} \mathrm{C}$. The $E$. coli cells transformed with the reconstructed plasmid will produce green fluorescent $c f u$, when observed using a $300 \mathrm{~nm}$ UV lamp.

Growing cells from green fluorescent cfu to produce the RBD-FP-sfGFP fusion protein. We will select a $15 \mathrm{ml}(16 \mathrm{~mm} \times$ $125 \mathrm{~mm}$ ) microbial culture tube containing $5 \mathrm{ml}$ sterile LB-Amp broth, warm it up at $37^{\circ} \mathrm{C}$ for five minutes and add $16 \mu l$ filter sterilized $100 \mathrm{mM}$ IPTG solution into the tube reaching a concentration of $0.4 \mathrm{mM}$ IPTG. Then, we will select a green fluorescent $c f u$ from the culture plate, add the cells into the tube, mix gently and grow the cells overnight at $37^{\circ} \mathrm{C}$.

Transcription of the SARS-CoV-2 RBD-FP-sfGFP containing $O R F$ from the recombined plasmid will be stimulated by the T7 promoter and regulated by the T7 RNA polymerase produced by E. coli, $\mathrm{C} 2566 \mathrm{H}$, that carries a genomic copy of the T7 RNA polymerase gene inducible by IPTG. Hence, the transformed E. coli, C2566H, will produce SARS-CoV-2 RBD-FP-sfGFP fusion protein from the reconstructed plasmid. ${ }^{32-34}$ 
Similar to the RBD-sfGFP fusion protein, the RBD-FP-sfGFP fusion protein will retain its green fluorescence at UV $300 \mathrm{~nm}$. This is supported by the fact that the RBD-sfGFP fusion protein produced by the Addgene plasmid, 141184, expresses green fluorescence in E. coli carrying T7 RNA polymerase. ${ }^{35-37}$

A comparison of the recombinant RBD protein with the Addgene, 141184, RBD protein sequences are presented in the results section.

\section{Extraction of RBD-FP-sfGFP fusion protein}

Pipette out $1.5 \mathrm{ml}$ cell culture from the tube into a $1.5 \mathrm{ml}$ microfuge tube, centrifuge it at $5,000 \mathrm{~g}$ for 10 minutes at $4^{\circ} \mathrm{C}$, pour off the supernatant, add $250 \mu \mathrm{l} 1 \mathrm{X}$ TE buffer into the cell pellet, gently resuspend the cells in the pellet by pipetting up and down the buffer along with the cell pellet, add $50 \mu 1$ lysozyme solution (Millipore-Sigma, Cat \# L3790) reaching a final concentration of $0.2 \mathrm{mg}$ lysozyme $/ \mathrm{ml}$, mix well, and incubate in a shaker at room temperature for 15 minutes. This will break open the cells and release the RBD-FP-sfGFP fusion protein into the buffer, centrifuge the solution at $2000 \mathrm{~g}$ for 10 minutes at $4^{\circ} \mathrm{C}$, collect the supernatant containing the RBD-FP-sfGFP fusion protein, and observe the solution using UV $300 \mathrm{~nm}$. The presence of RBD-FP-sfGFP fusion protein in solution will be indicated by a fluorescent green colour in UV $300 \mathrm{~nm}$. Hold the tube containing the extract at $4^{\circ} \mathrm{C}$ for further use.

\section{Separation of RBD protein from RBD-FP-sfGFP fusion protein}

The RBD-FP-sfGFP fusion protein will be separated by HIC (hydrophobic interaction chromatography) using a $B I O$ $R A D$ protein extraction kit (Cat \#166-0005EDU), https://www.bio-rad.com/webroot/web/pdf/lse/literature/4006099. pdf, using the following steps:

1. Using a pair of scissors, cut off the bottom of the hydrophobic resin prefilled HIC column.

2. Place the column into a $5 \mathrm{ml}$ test tube in a stable rack.

3. Remove the top cap of the column and allow the buffer to drain out up to the top level of the resin in the column.

4. Add $2 \mathrm{ml} 2 \mathrm{M}\left(\mathrm{NH}_{4}\right)_{2} \mathrm{SO}_{4}$ solution on top of the resin and allow it to drain out up to the top level of the resin.

5. Put back the cap on top of the column to stop draining.

6. Side-by-side, add $250 \mu \mathrm{l}$ RBD-FP-sfGFP fusion protein extract into another microfuge tube.

7. Add $250 \mu \mathrm{l} 4 \mathrm{M}\left(\mathrm{NH}_{4}\right)_{2} \mathrm{SO}_{4}$ solution and mix well.

8. Transfer the solution into the column (Figure 6, Step 1).

9. Allow the buffer to drain out up to the top level of the resin in the column into a collection tube; discard the fluid from the collection tube.

10. Add $250 \mu \mathrm{l} 1.3 \mathrm{M}\left(\mathrm{NH}_{4}\right)_{2} \mathrm{SO}_{4}$ solution into the column and drain out the fluid up to the top level of the resin into the collection tube; discard the fluid (Figure 6, Step 2).

The discards will contain all unwanted bacterial protein contaminants while the RBD-FP-sfGFP fusion protein will remain attached to the resin beads in the column.

11. In a separate microfuge tube, add $2 \mu \mathrm{l}$ enterokinase (NEB, Cat \#P8070) in $8 \mu \mathrm{l}$ of its reaction buffer, $20 \mathrm{mM}$ Tris- $\mathrm{HCl}, 50 \mathrm{mM} \mathrm{NaCl}, 2 \mathrm{mM} \mathrm{CaCl}_{2}, \mathrm{pH}$ 8.0, and mix well. Add $2 \mu \mathrm{l}$ buffered enterokinase (NEB Cat \#P8070) into the column (Figure 6, Step 3).

12. Incubate the column at $25^{\circ} \mathrm{C}$ for two hours. This will degrade the FP and thus separate the RBD from the sfGFP from the fusion protein.

13. Add $750 \mu \mathrm{l} 1.3 \mathrm{M}\left(\mathrm{NH}_{4}\right)_{2} \mathrm{SO}_{4}$ solution into the column and elute the RBD protein into a UV transparent collection tube and save (Figure 6, Step 4). The sfGFP will remain bound to the resin. 
14. Take out the collection tube with the eluate, view the eluate using a UV $300 \mathrm{~nm}$ lamp. Pure eluate will not emit green fluorescence. The top of the resin column holding the sfGFP will emit green fluorescence at UV $300 \mathrm{~nm}$.

Separation of the RBD protein from the RBD-FP-sfGFP fusion protein after the enterokinase (NEB Cat \#P8070) digestion of the FP will be completed by HIC. This is a routine technique to isolate non-hydrophobic proteins from hydrophobic proteins. In this digestion, the enterokinase will digest the DDDDKRS fusion peptide in between DDDDK and RS, leaving DDDDK fused with the RBD protein at its C-terminal. The remaining RS dipeptide will remain fused with the GGSGSG, forming RSGGSGSG. This residue will remain fused with the sfGFP at its N-terminal. Since the sfGFP present in the RBD-FP-sfGFP fusion protein is strongly hydrophobic, the RBD-FP-sfGFP fusion protein will bind to the resins in the HIC column. Once the enterokinase completes the digestion, the RBD protein will become separated from the sfGFP. The separated RBD protein will be eluted by $1.3 \mathrm{M}\left(\mathrm{NH}_{4}\right)_{2} \mathrm{SO}_{4}$ buffer from the hydrophobic resins in the column, leaving the sfGFP protein bound to the resins (Figure 6).

\section{Removal of $\left(\mathrm{NH}_{4}\right)_{2} \mathrm{SO}_{4}$ from RBD protein eluate by dialysis}

The RBD protein eluate from the hydrophobic column will contain approximately $1.3 \mathrm{M}\left(\mathrm{NH}_{4}\right)_{2} \mathrm{SO}_{4}$ and stray molecules of enterokinase. The enterokinase molecules will be removed by using an enterokinase removal kit (Sigma-Aldrich, Cat \# PRKE) followed by the removal of $\left(\mathrm{NH}_{4}\right)_{2} \mathrm{SO}_{4}$ as follows:

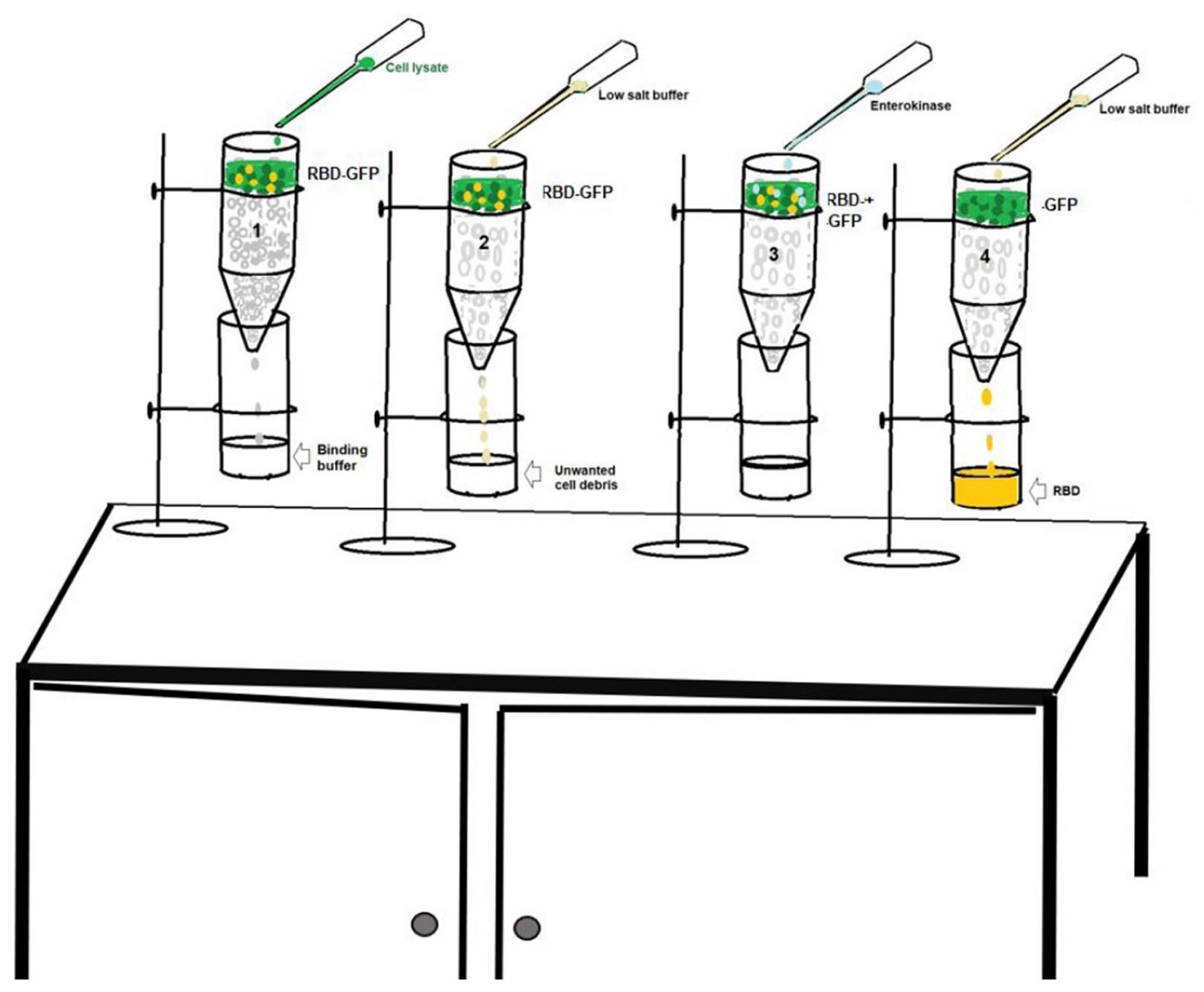

Figure 6. Hydrophobic Interaction Chromatography (HIC) to elute the RBD from the sfGFP. Step 1. Protein extract from Escherichia coli, $\mathrm{C} 2566 \mathrm{H}$, cells transformed with the recombined plasmid and treated with the equilibrium buffer $\left(4 \mathrm{M}\left(\mathrm{NH}_{4}\right)_{2} \mathrm{SO}_{4}\right)$ ) is being pipetted into the hydrophobic ion exchange column, already equilibrated with a high salt buffer $\left(2 \mathrm{M}\left(\mathrm{NH}_{4}\right)_{2} \mathrm{SO}_{4}\right)$ ). This will allow RBD-FP-sfGFP fusion protein to bind tightly into the resins in the column. Step 2. A low salt buffer $\left.\left(1.3 \mathrm{M}\left(\mathrm{NH}_{4}\right)_{2} \mathrm{SO}_{4}\right)\right)$ is added to wash away the unwanted cell extract, while keeping the RBD-FP-sfGFP fusion protein bound to the column resins. Step 3. Enterokinase is being added to digest the FP to separate the RBD from the sfGFP proteins. Step 4. A low salt buffer $\left.\left(1.3 \mathrm{M}\left(\mathrm{NH}_{4}\right)_{2} \mathrm{SO}_{4}\right)\right)$ is added to elute the RBD proteins, keeping the sfGFP protein bound to the resins in the column. 
1. Add $50 \mu \mathrm{l}$ anti-enterokinase-agarose conjugate pellet (following Sigma-Aldrich, PRKE protocol) to the RBD eluate, mix gently; centrifuge at $1000 \mathrm{~g}$ for 2 minutes at $4^{\circ} \mathrm{C}$; collect the supernatant containing RBD and $<1.3 \mathrm{M}$ $\left(\mathrm{NH}_{4}\right)_{2} \mathrm{SO}_{4}$. Add v/v Tris-buffer containing $20 \mathrm{mM}$ Tris, $200 \mathrm{mM} \mathrm{NaCl}, \mathrm{pH} 8.0$ to the RBD eluate.

2. Take a SnakeSkin dialysis tube prehydrated with the above buffer and close one of its ends with a clip.

3. Place the RBD eluate into the SnakeSkin dialysis tube and close the other end with another clip. ${ }^{38,39}$

4. Place the dialysis tube in the Tris-buffer at $4^{\circ} \mathrm{C}$ in a dish for two hours.

5. Transfer the dialysis tube into fresh Tris-buffer two more times and run the dialysis for two hours each.

6. Transfer the dialyzed eluate into a fresh sterile proteinase-free sterile tube and store at $4^{\circ} \mathrm{C}$ for further tests.

Removal of $\left(\mathrm{NH}_{4}\right)_{2} \mathrm{SO}_{4}$ from a protein extract using dialysis is a routine procedure. ${ }^{40-42}$ Berndt, et al. ${ }^{43}$ ligated cDNAs of an RBD protein of SARS-CoV-2 with a cDNA coding for a 5'mClover green fluorescent protein gene, which was expressed by a transformed Chlamydomonas reinhardtii. The RBD-mClover fusion protein, expressed by $C$. reinhardtii, was separated by HIC. ${ }^{43}$ The eluate RBD molecules retained its full immunogenic activity, as observed by its ability to bind to ACE-2 receptor proteins. ${ }^{43}$ This supports that $\left(\mathrm{NH}_{4}\right)_{2} \mathrm{SO}_{4}$ does not affect the structural integrity of the RBD proteins. Furthermore, $\left(\mathrm{NH}_{4}\right)_{2} \mathrm{SO}_{4}$ is known to stabilize the 3D structure of proteins. ${ }^{44}$ Park, et al., ${ }^{45}$ isolated recombinant colorectal cancer vaccine protein, GA733-FcK, using 50\% (5.05M) $\left(\mathrm{NH}_{4}\right)_{2} \mathrm{SO}_{4}$ in its active form. Hence, we predict $1.3 \mathrm{M}\left(\mathrm{NH}_{4}\right)_{2} \mathrm{SO}_{4}$ solution used in this protocol will have no impact on the 3D structure of the RBD protein.

Tan, et al., ${ }^{42}$ dialyzed RBD-SpyVLP eluate for 16 hours in Tris-buffered saline (TBS). In our protocol, we propose to use a Tris-buffer ( $20 \mathrm{mM}$ Tris, $200 \mathrm{mM} \mathrm{NaCl}, \mathrm{pH}$ 8.0) to the RBD eluate, $\mathrm{v} / \mathrm{v}$, and put it into a SnakeSkin dialysis tube (Thermo Fisher Scientific, Cat \#88243) with a $10 \mathrm{kDa}$ cut-off, following Tai, et al. ${ }^{39}$ Since the molecular weight of RBD protein monomer is $25 \mathrm{kDa}$, the porosity of the SnakeSkin dialysis tube will save the RBD protein inside the tube while allowing $\left(\mathrm{NH}_{4}\right)_{2} \mathrm{SO}_{4}$ to leach out. Upon completion of the dialysis, storing RBD protein in Tris-buffer, $\mathrm{pH} 8.0$, at $4{ }^{\circ} \mathrm{C}$ will save the RBD protein from bacterial and enzymatic degradation.

Determination of RBD proteins eluate by SDS-PAGE, Tee, et $a l_{.}{ }^{46}$

We will be using SDS-PAGE NuPAGE 4-12\% gradient gel for the electrophoresis as follows:

1. Place the NuPAGE into a Mini Gel Tank, Thermo Fisher Scientific, Cat \# A25977.

2. Fill in the chamber with $1 \times$ NuPAGE MES SDS Running Buffer up to the designated level.

3. Put $5 \mu$ Protein Standard in $1 \times$ solution buffer into a well of SDS-PAGE gel.

4. Put $5 \mu$ dialyzed RBD protein sample in $1 \times$ sample buffer into a parallel well in the SDS-PAGE gel.

5. Run the electrophoresis using an Invitrogen PowerEase Touch 600W Power Supply, Thermo Fisher Scientific, Cat \# PS0601, at $200 \mathrm{~V}$ and 30 - $40 \mathrm{mAmp}$ for 40 minutes.

6. Remove the NuPAGE gel slab and stain it with InstantBlue, following the supplier's protocol.

7. Measure in $\mathrm{cm}$, using a ruler, the distances traveled by each of the Protein Standard bands as well as by the RBD protein bands and record them in a notebook to be used next for plotting and measurement.

8. Plot a protein standard graph in a semi-log paper using the distance, in $\mathrm{cm}$, traveled by each standard protein band on the $\mathrm{Y}(\log )$ axis and their respective molecular sizes on the $\times$ (linear) axis.

9. Determine the molecular sizes of the RBD protein bands using the protein standard graph, prepared above. The expected sizes of the RBD proteins will be 221 aa $(24.3 \mathrm{kDa})$ for monomers, 442 aa $(48.6 \mathrm{kDa})$ for dimers and 663 aa $(72.9 \mathrm{kDa})$ for trimers. 
The SDS-PAGE procedure separates proteins primarily by mass, since SDS denatures and binds to proteins to make them negatively charged. Hence, in an electric field, the SDS-bound RBD proteins will migrate through the gel toward the positively charged electrode based on its mass. A protein molecule of a lower mass size will have higher mobility in comparison to a protein molecule of higher mass size.

This procedure will help us determine the molecular sizes of the RBD proteins in the eluate and compare them with known values.

Immunoreactivity of the dialyzed RBD sample

We will test $1 \mu \mathrm{l}$ sample of the dialyzed RBD protein for immunoactivity using a SARS-CoV-2 RBD Elisa kit, BioVision, Cat \# E4877, for a qualitative determination of the RBD protein, following the supplier's protocol.

This procedure follows the ELISA principle. It contains SARS-CoV-2 RBD protein samples in solutions, detection solutions, pre-coated RBD antibodies, and all necessary ingredients. This technique is known to be highly sensitive, detecting $<10 \mathrm{pg} \mathrm{RBD} / \mathrm{ml}$.

In this protocol, a standard RBD concentration graph will be plotted using $\mathrm{OD}_{450 \mathrm{~nm}}$ of RBD samples of known concentrations. This will be accomplished by a tagged RBD-antibody-RBD-antigen binding, followed by a chromogenic reaction. An RBD sample from the dialyzed eluate will be tested using the same RBD-antibody-RBD-antigen binding followed by the chromogenic reaction and $\mathrm{OD}_{450 \mathrm{~nm}}$ measurement. Based on the $\mathrm{OD}_{450 \mathrm{~nm}}$ of the dialyzed RBD protein sample, its concentration will be determined from the standard graph. This procedure will help vaccine development in two ways: it will detect the presence of RBD protein in the HIC eluate that is purified by dialysis, and it will measure the concentration of RBD protein antigen present in the dialyzed sample.

The modification of the RBD protein will not affect its immunogenic ability as demonstrated by Keng, et al. ${ }^{47} \mathrm{Keng}$, et al., ${ }^{47}$ in an antibody neutralization experiment demonstrated that fragmented spike protein DNA containing variable lengths of RBD proteins, expressed by transformed E. coli, retained the immunogenic ability against SARS-CoV-2 virus. Furthermore, this modification will not affect the internally located RBM, the epitope of the RBD protein. ${ }^{29}$ The RBD antigen thus produced can be applied as a safer vaccine after formulation for trials as described by Batty, et al. ${ }^{48}$

\section{RBD quantitation using spectrophotometry}

We will take a $10 \mu \mathrm{l}$ sample of the dialyzed RBD protein and determine its concentration by measuring OD at UV $280_{\mathrm{nm}}$ using a UV-Vis spectrophotometer following Arbeitman, et al. ${ }^{49}$ The total amount of RBD protein in the dialyzed sample will be equal to $\mathrm{M}=(\mathrm{OD} \div \mathrm{L}) \mathrm{x}$. (Where, $\mathrm{M}=$ amount of $\mathrm{RBD}$ protein present in $\mathrm{mg}$ per $\mathrm{ml}$ in the original sample; $\mathrm{OD}=$ Optical density at $280_{\mathrm{nm}} ; \mathrm{L}=$ the length of cuvette light path in $\mathrm{cm} ; \mathrm{D}=$ dilution factor. $)^{50,51}$

\section{Evaluation of the modified RBD protein $\beta$ sheet}

The RBD protein sequences, before (Figure 7) and after modification (Figure 8) will be tested for their alignments with known 2019-nCoV RBD protein sequence available through a computerized program, UniProt Protein Blast (UniProtKB: P00750): https://www.uniprot.org/blast/.

The details of the alignment are presented in the results section following Figure 9 and Figure 10, below:

Storage of RBD protein for future use

Add a measured volume of glycerol to the dialyzed RBD solution, reaching a final concentration of $10 \%$ (v/v) glycerol in the solution and mix well. Make aliquots of the RBD solution in separate pre-laveled micro-vials, freeze them quickly in liquid nitrogen, and store them in a $-80^{\circ} \mathrm{C}$ freezer following Tee, et al. ${ }^{46}$

The aliquots of RBD can be reused for vaccine formulations as needed. Edwards, et al. ${ }^{52}$ have observed under electron microscopy that RBD molecules stored at $22^{\circ} \mathrm{C}$ or $37^{\circ} \mathrm{C}$ in a buffer $(2 \mathrm{mM}$ Tris, pH8.0, $200 \mathrm{mM} \mathrm{NaCl}, 0.02 \%$ sodium azide) for one week displayed well-ordered trimeric structure. ${ }^{52}$ Hence, we anticipate that the quick-frozen RBD monomers, isolated in the protocol, will form dimers and trimers after thawing at $22^{\circ} \mathrm{C}$ or $37^{\circ} \mathrm{C}$, as a natural phenomenon. Since both the RBD dimers and trimers have higher ACE-2 binding activity than its monomers, the dimerization and trimerization will increase vaccination efficacy of the isolated RBD proteins. ${ }^{53,54}$

\section{Projected results}

Comparison of the RBD proteins before and after the recombination

The original plasmid, Addgene, 141184, carries a 639 bp long RBD cDNA linked with a 714 bp long sfGFP cDNA (Figure 5A). The RBD cDNA will code for a 221 amino acid long RBD protein as shown in Figure 7. 


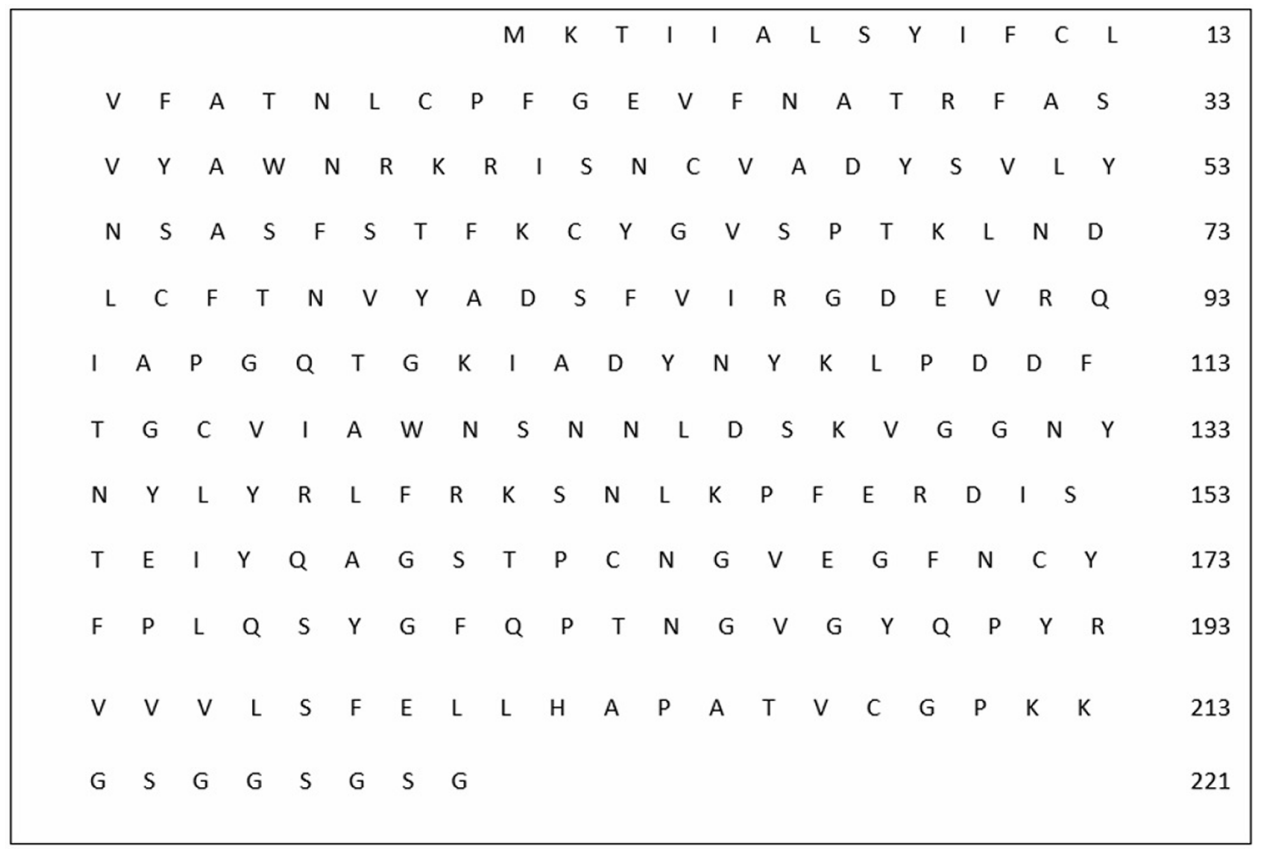

Figure 7. The amino acid sequence of the RBD protein (221 aa long) produced by the Addgene plasmid, 141184.

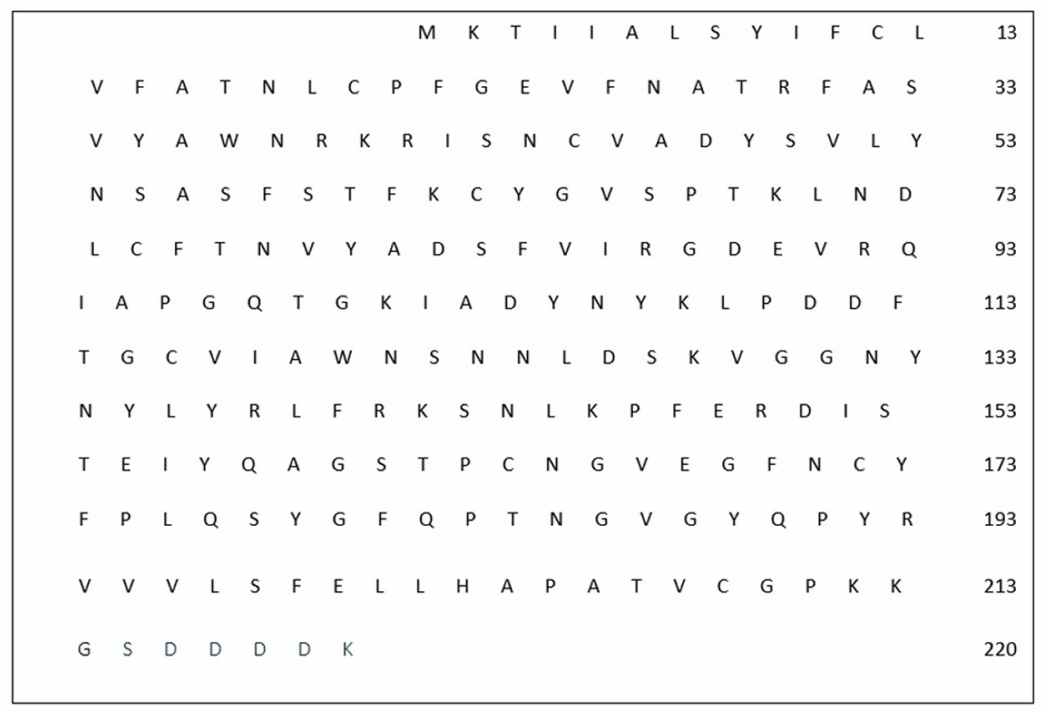

Figure 8. The amino acid sequence of the RBD protein (215 aa long) fused with the FP (DDDDK) (5 aa) at the C-terminal encoded by the recombined plasmid.

The modified RBD protein encoded by the recombined plasmid is shown in Figure 8. As mentioned earlier, the modified RBD protein will have a five amino acid long FP (DDDDK) replacing six amino acids (GGSGSG) at its C-terminal (Figure 8).

The modified RBD protein $\beta$ sheet remains unchanged

The RBD protein $\beta$ sheet, critical for its 3D structure, will also remain fully stable since the modification of the RBD protein at the C-terminal has no effect on the pairing of the sulfur containing amino acid Cys336-Cys361, Cys379Cys432, and Cys391-Cys525. ${ }^{29}$ We proved this by aligning the RBD protein sequences, before and after modification, with the RBD sequence produced by the 2019-nCoV genome using a computerized program, UniProt Protein Blast (UniProtKB: P00750), https://www.uniprot.org/blast/as), as shown in Figure 9 and Figure 10. 


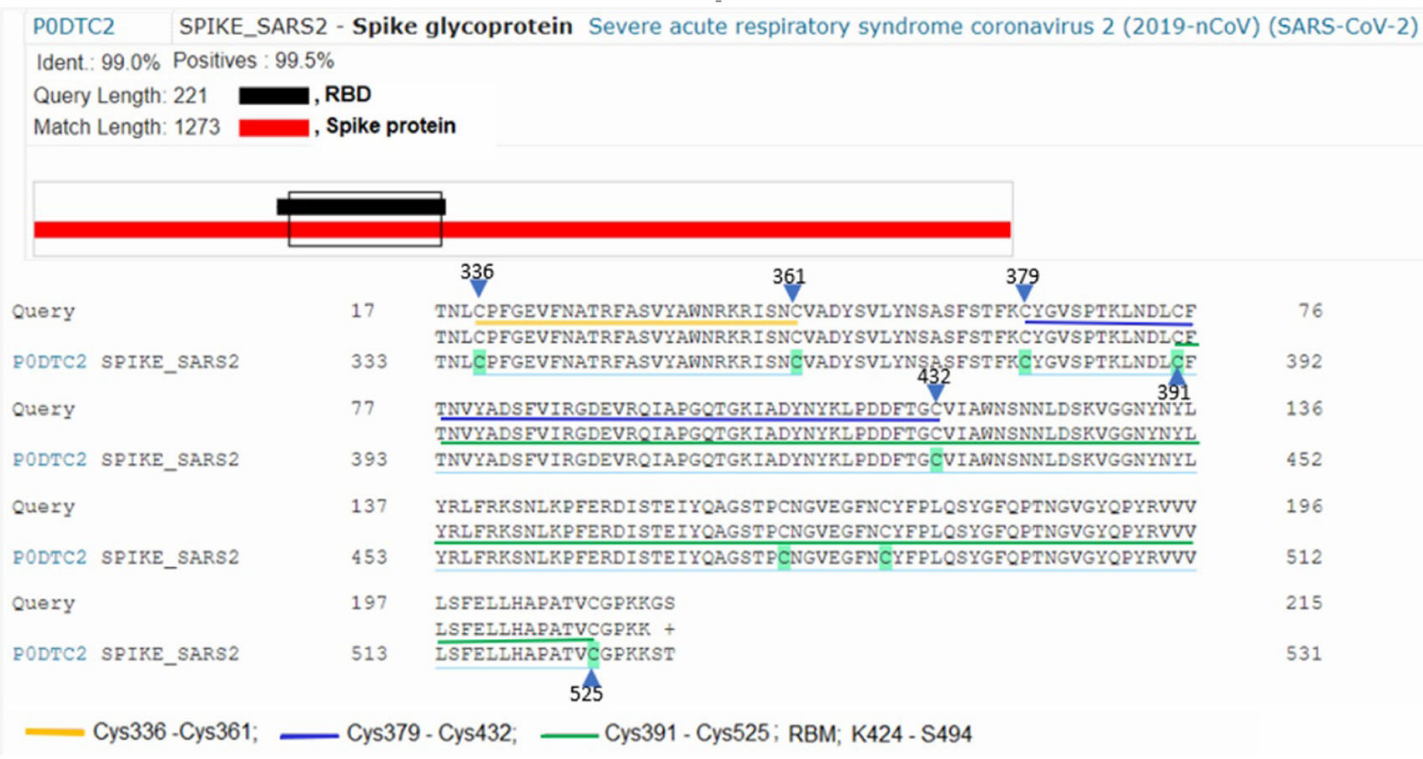

Figure 9. Alignment of the RBD protein encoded by Addgene, 141184, with the RBD protein generated by 2019nCoV, SARS-CoV-2 virus, for comparison, using UniProtKB: P00750.

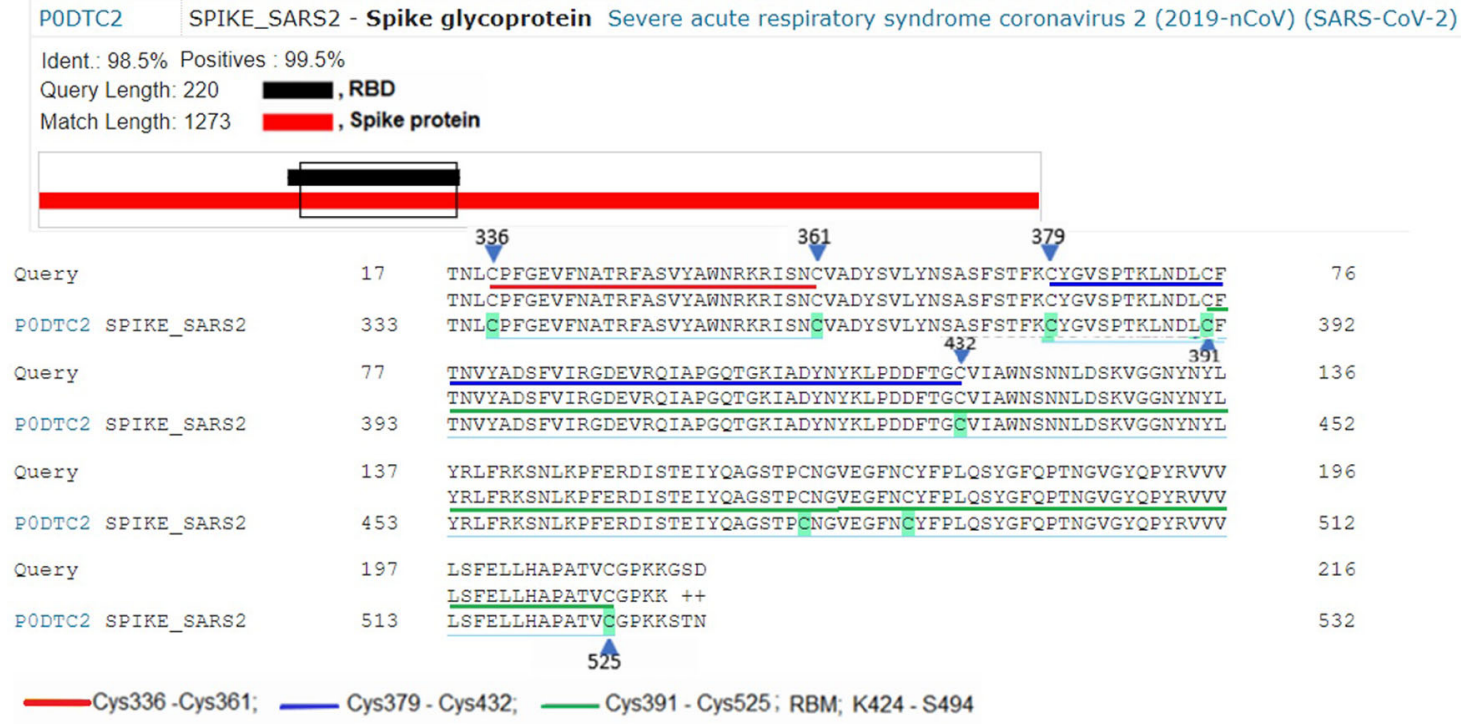

Figure 10. Alignment of modified RBD protein encoded by the recombinant plasmid with the RBD protein generated by 2019-nCoV, SARS-CoV-2 virus, for comparison, using UniProtKB: P00750.

As shown in Figure 9, the RBD protein encoded by the RBD cDNA, Addgene, 141183, matches perfectly with the respective RBD protein sequence produced by 2019-nCoV strain of the SARS-CoV-2 coronavirus. Three pairs of CysCys residues, Cys336-Cys361, Cys379-Cys432 and Cys391-Cys525, encoded by the RBD cDNA, responsible for the core RBD protein $\beta$ sheet formation, match perfectly with the respective RBD protein sequence produced by the 2019nCoV strain. The total amino acid length of the RBD protein encoded by the RBD cDNA, Addgene, 141183, is 221, which has $99.0 \%$ identity match and $99.5 \%$ positivity match with the RBD protein sequence produced by the $2019-\mathrm{nCoV}$ (Figure 9).

Similarly, as shown in Figure 10, the RBD protein encoded by the modified RBD cDNA matches perfectly with the respective RBD protein sequence generated by 2019-nCoV strain of the SARS-CoV-2 coronavirus. Three pairs of CysCys residues, Cys336-Cys361, Cys379-Cys432 and Cys391-Cys525, encored by the modified RBD cDNA, that form the 
core RBD protein $\beta$ sheet, match perfectly with the respective RBD protein sequence produced by the $2019-\mathrm{nCoV}$ strain. The total amino acid length of RBD protein encoded by the modified RBD cDNA is 220, which has $98.5 \%$ identity match and $99.5 \%$ positivity match with the RBD protein sequence produced by the $2019-\mathrm{nCoV}$.

\section{Discussion}

The protocol we designed to produce the SARS-CoV-2 RBD antigen, which is responsible for recognition and attachment to the ACE-2 receptors in human cells, is a novel one. Since the RBD protein is not linked to the S2 domain protein, the RBD protein, after binding to ACE-2, will not allow any free-floating virions to enter any human cell. Additionally, the RBD protein alone was found to have effective immunological integration with eight types of ACE- 2 variants in human cells. ${ }^{55}$ This observation supports that the RBD protein produced by this protocol will remain effective in multiple human recipients, despite their ACE-2 variations. Other authors reported that a single dose of the RBD antigen vaccine delivered to mice has produced a high titer of antibodies effective against both mutant and non-mutant variants of the SARS-CoV-2 virus. ${ }^{56}$

An RBD protein sample, similar to the RBD protein produced by this protocol, was found to induce a potent and functional antibody production in mice, rabbits, and non-human primates (Macaca mulatta) within seven to 14 days following single dose administrations. ${ }^{57}$ It was also found that the SARS-CoV-2 RBD protein is a highly effective antigen to work as a vaccine by Dai and Gao. ${ }^{53}$ Both RBD-dimer and RBD-trimer proteins have been found to increase the immunogenicity of RBD-protein based vaccines effectively, in comparison to RBD protein monomers. ${ }^{53}$ RBD proteins, produced by this protocol, will form trimers in a solution as supported by Edwards, et al. ${ }^{52}$ All the above reports support that the RBD protein produced by this protocol has the full potential to be an effective vaccine against the SARS-CoV-2 and some of its mutants.

The purified RBD protein molecules become dimers by forming four disulfide bonds between two RBD monomers. ${ }^{46}$ Furthermore, the RBD dimers are also much more effective than its monomers in stimulating antibody production (10-100 times immunogenicity) and in neutralizing SARS-CoV and SARS-CoV-2 antibodies. ${ }^{54}$ Hence, the RBD protein is a strong vaccine candidate and also potentially effective against multiple coronaviruses: SARS-CoV, MERS-CoV, and SARS-CoV-2. ${ }^{54}$ The yield of RBD dimerization from its monomer is high and its production level may be scaled up in order to meet clinical demands. ${ }^{54}$

Development of a more effective vaccine is the main target of this study protocol. The RBD vaccine antigen, once recognized by the T-cells, will promote secretion of cytokine interferon gamma and interleukin-2 biomarkers, which will stimulate the helper and cytotoxic T cells, B cells, and protective IgG antibodies. ${ }^{58}$

Furthermore, since the glycan shield of the beta-coronavirus $(\beta-\mathrm{CoV})$ spike glycoprotein acts as a steric block that prevents host immune responses (and thus reduces antibody production), the RBD monomer does not need to be glycosylated, as supported by Henderson, et al. ${ }^{59}$

\section{Conclusion}

The RBD protein is an excellent choice for developing a vaccine to prevent COVID-19. The vaccines composed of antigenic mRNA and cDNA are required to go through cellular processes to produce antigens. The RBD protein itself is an antigen and, hence, it will be direct and quick in stimulating the recipients' immune systems to produce antibody against SARS-CoV-2 virions quickly.

The SARS-CoV-2 RBD protein vaccine can generate a strong immune response and can be used by almost everyone, including people with weakened immune systems and long-term health problems as supported by the United States Department of Health and Human Services. Furthermore, the RBD protein vaccines cannot cause the COVID-19 disease. However, while using the RBD protein vaccine, booster shots may be necessary for immunome compromised recipients to gain sufficient protection against the ongoing SARS-CoV-2 infections.

The RBD protein production and purification protocol that we are proposing is seamless. Hence, the RBD protein thus produced can be used to prepare a vaccine following a standard formulation procedure and clinical trials.

\section{Dissemination}

The authors are planning to apply for a National Institutes of Health grant in due course to support this project and execute it. After receiving a grant and access to the academic laboratory for the authors is released from the pandemic restrictions, the authors will conduct their research based on this protocol, approved by the IRB, and make their findings available through open access, online, present in conferences and publish in peer reviewed journals. 
Data availability

No data are associated with this article.

\section{Acknowledgements}

We would like to acknowledge the contributions made by the editors, Arnab Z. Jahangir, B.Sc. and Dr. Arthee E. Jahangir, Ph.D., and thank them for their editorial support.

A previous version supporting this article can also be found on preprints.org. ${ }^{1}$ One of the authors, Arleta H. Marnik, presented "A Protocol for Producing SARS-CoV-2 RBD Vaccine" at a three-day long 2021 CUNY Research Scholars Summer Symposium, held during July 27-29, 2021. The protocol was highly accepted by the CUNY research scholars present and Mrs. Marnik was one of the winners in the competition receiving a certificate of an award. A list of the winners is available here.

\section{References}

1. Jahangir ZS, Marnik AH: A Review of SARS-CoV-2, Responsible for COVID-19: History, Biology, Infection Mechanism, Antigenic Vaccines, Their Risks and how an Alternate RBD Vaccine is Safer? Preprints. 2021, 2021060377.

Publisher Full Text

2. Woo PC, Lau SK, Lam CS, et al.: Discovery of seven novel mammalian and avian coronaviruses in the genus Deltacoronavirus supports bat coronaviruses as the gene source of Alphacoronavirus and Betacoronavirus and avian coronaviruses as the gene source of Gammacoronavirus and Deltacoronavirus. J Virol. 2012; 86(7): 3995-4008. PubMed Abstract | Publisher Full Text | Free Full Text

3. Chan JF-W, To KK-W, Tse $\mathrm{H}$, et al.: Interspecies transmission and emergence of novel viruses: lessons from bats and birds Jasper. Trends Microbiol. 2013; 21(10): 544-555.

PubMed Abstract | Publisher Full Text | Free Full Text

4. Tyrrell $D$, Bynoe M: Cultivation of viruses from a high proportion of patients with colds. Lancet. 1966; 287(7428): 76-77. PubMed Abstract | Publisher Full Text

5. Kapikian AZ: The coronaviruses. Dev Biol Stand. 1975; 28: 42-64. PubMed Abstract

6. Kahn JS, McIntosh K: History and recent advances in coronavirus discovery. Pediatr Infect Dis J. 2005; 24(11): S223-S227. PubMed Abstract | Publisher Full Text

7. Edridge AWD, Kaczorowska J, Hoste ACR, et al.: Seasonal coronavirus protective immunity is short-lasting. Nat Med. 2020; 26, 1691-1693.

PubMed Abstract | Publisher Full Text

8. $\mathrm{XuRH}, \mathrm{HeJF}$, Evans MR, et al.: Epidemiologic clues to SARS origin in China. Emerg Infect Dis. 2004; 10(6): 1030-1037. PubMed Abstract | Publisher Full Text | Free Full Text

9. Shi Z, Hu Z: A review of studies on animal reservoirs of the SARS coronavirus. Virus Res. 2008; 133(1): 74-87. PubMed Abstract | Publisher Full Text | Free Full Text

10. Li X, Zai J, Zhao Q, et al.: Evolutionary history, potentia intermediate animal host, and cross-species analyses of SARSCoV-2. J Med Virol. 2020; 92(6): 602-611. PubMed Abstract | Publisher Full Text | Free Full Text

11. Wang $\mathrm{H}, \mathrm{Li} X, \mathrm{Li} \mathrm{T}$, et al.: The genetic sequence, origin, and diagnosis of SARS-CoV-2. Eur J Clin Microbiol Infect Dis: officia publication of the European Society of Clinical Microbiology. 2020; 39(9): 1629-1635.

PubMed Abstract | Publisher Full Text | Free Full Text

12. Mackay IM, Arden KE: MERS coronavirus: Diagnostics, epidemiology and transmission. VirolJ. 2015; 12(1): 222-243. PubMed Abstract | Publisher Full Text | Free Full Text

13. Zumla A, Hui DS, Perlman S: Middle East respiratory syndrome. Lancet. 2015; 386(9997): 995-1007.

PubMed Abstract | Publisher Full Text | Free Full Text

14. Coleman CM, Sisk JM, Mingo RM, et al.: Abelson Kinase Inhibitors Are Potent Inhibitors of Severe Acute Respiratory Syndrome Coronavirus and Middle East Respiratory Syndrome Coronavirus Fusion. J Virol. 2016; 90(19): 8924-8933.

PubMed Abstract | Publisher Full Text | Free Full Text
15. Killerby ME, Biggs HM, Midgley CM, et al.: Middle East Respiratory Syndrome Coronavirus Transmission. Emerging Infectious Dis. 2020; 26(2): 191-198. Publisher Full Text

16. Lu X, Mu Z, Deyton M, et al.: Cold sensitivity of the SARS-CoV-2 spike ectodomain. 2020 Publisher Full Text

17. Sanjuán R, Domingo-Calap P: Mechanisms of viral mutation. Cell Mol Life Sci. 2016; 73(23): 4433-4448. PubMed Abstract | Publisher Full Text | Free Full Text

18. Mallory ML, Lindesmith LC, Baric RS: Vaccination-induced herd immunity: Successes and challenges. J Allergy Clin Immunol. 2018; 142(1): 64-66.

PubMed Abstract | Publisher Full Text | Free Full Text

19. Agrawal G, Conway M, Heller J, et al.: On pins and needles: Will COVID-19 vaccines 'save the world'? McKinsey \& Company. Pharmaceutical \& Medical Products Practice. Pages. 2020: 1-16. Reference Source

20. Moshiri N: Coronavirus seems to mutate much slower than seasonal flu. Live Science. 2020 Reference Source

21. Zhang $\mathrm{L}$, Jackson $\mathrm{CB}$, Mou $\mathrm{H}$, et al.: The D614G mutation in the SARS-CoV-2 spike protein reduces $\mathbf{S 1}$ shedding and increases infectivity. bioRxiv. June 12, 2020, biorxiv.com; bioRxiv 2020.12.12.422516; Publisher Full Text

22. Plante JA, Liu Y, Liu J, et al.: Spike mutation D614G alters SARS-CoV2 fitness. Nature. 2020

PubMed Abstract | Publisher Full Text | Free Full Text

23. Rausch JW, Capoferri AA, Katusiime MG, et al.: Low genetic diversity may be an Achilles heel of SARS-Cov-2. Proc Natl Acad SCi US A. 2020; 117(40): 24614-24616. PubMed Abstract | Publisher Full Text | Free Full Text

24. Huang Y, Yang C, Xu X, et al.: Structural and functional properties of SARS-Cov-2 spike protein: Potential antivirus drug development for COVID-19. Acta Pharmacologica Sinica. 2020 41(9): 1141-1149. PubMed Abstract | Publisher Full Text | Free Full Text

25. Yuan $\mathrm{M}, \mathrm{Wu} \mathrm{NC}$, Zhu X, et al.: A highly conserved cryptic epitope in the receptor-binding domains of SARS-CoV-2 and SARS-CoV. Science. 2020.

PubMed Abstract | Publisher Full Text | Free Full Text

26. Yang J, Petitjean SJL, Koehler M, et al.: Molecular interaction and inhibition of SARS-CoV-2 binding to the ACE-2 receptor. Nat Commun. 2020; 11: 4541

PubMed Abstract | Publisher Full Text | Free Full Text

27. Yi C, Sun X, Ye J, et al.: Key residues of the receptor binding motif in the spike protein of SARS-Cov-2 that interact with ACE2 and neutralizing antibodies. Cell Mol Immunol. 2020; 17(6): 621-630. PubMed Abstract | Publisher Full Text | Free Full Text

28. Khalaj-Hedayati A: Protective Immunity against SARS Subunit Vaccine Candidates Based on Spike Protein: Lessons for Coronavirus Vaccine Development. J Immunol Res. 2020; 2020: 7201752.

PubMed Abstract | Publisher Full Text | Free Full Text 
29. Lan J, Ge J, Yu J, et al.: Structure of the SARS-Cov-2 spike receptorbinding domain bound to the ACE2 receptor. Nature. 2020; 581 (7807): 215-220

PubMed Abstract | Publisher Full Text

30. Hassan R, Husin A, Sulong S, et al.: Guidelines for nucleic acid detection and analysis in hematological disorders. Malays J Pathol. 2015 Aug; 37(2): 165-73.

PubMed Abstract

31. Sambrook J, Russell DW: Preparation and transformation of Competent E. coli Using calcium chloride. Cold Spring Harbor Protocols. 2006; 2006(1), pdb.prot3932. Publisher Full Text

32. Kesik-Brodacka M, Romanik A, Mikiewicz-Sygula D, et al.: A novel system for stable, high-level expression from the T7 promoter. Microb Cell Fact. 2012; 11(1): 109.

PubMed Abstract | Publisher Full Text | Free Full Text

33. Anton BP, Fomenkov A, Raleigh EA, et al.: Complete Genome Sequence of the Engineered Escherichia coli Shuffle Strains and Their Wild-Type Parents. Genome Announc. 2016; 4(2): e00230-e00216.

PubMed Abstract | Publisher Full Text | Free Full Text

34. Lutz T, Flodman K, Copelas A, et al.: A protein architecture guided screen for modification dependent restriction endonucleases. Nucleic Acids Res. 2019; 47(18): 9761-9776.

PubMed Abstract | Publisher Full Text | Free Full Text

35. Pédelacq J, Cabantous S, Tran T, et al.: Engineering and characterization of a superfolder green fluorescent protein. Nat Biotechnol. 2005; 24(1): 79-88.

PubMed Abstract | Publisher Full Text

36. Cotlet M, Goodwin PM, Waldo GS, et al.: A comparison of the fluorescence dynamics of single molecules of a green fluorescent protein: One- versus two-photon excitation. ChemPhysChem. 2006; 7(1): 250-260. PubMed Abstract | Publisher Full Text

37. Frenzel $E$, Legebeke J, Van Stralen $A$, et al.: In vivo selection of sfGFP variants with improved and reliable functionality in industrially important thermophilic bacteria. Biotechnol Biofuels. 2018; 11(1).

PubMed Abstract | Publisher Full Text | Free Full Text

38. Azad T, Singaravelu R, Crupi MJ, et al.: Implications for SARS-CoV-2 vaccine design: Fusion of spike glycoprotein Transmembrane domain to receptor-binding domain induces Trimerization. Membranes. 2020; 10(9): 215.

PubMed Abstract | Publisher Full Text | Free Full Text

39. Tai W, He L, Zhang X, et al.: Characterization of the receptor-binding domain (RBD) of 2019 novel coronavirus: implication for development of RBD protein as a viral attachment inhibitor and vaccine. Cell Mol Immunol. 2020; 17, 613-620

PubMed Abstract | Publisher Full Text | Free Full Text

40. Xi CR, Di Fazio A, Nadvi NA, et al.: A novel purification procedure for active recombinant human DPP4 and the inability of DPP4 to bind SARS-Cov-2. Molecules. 2020; 25(22): 5392. PubMed Abstract | Publisher Full Text | Free Full Text

41. Wang W, Liu Q-J, Cui H: Rapid desalting and protein recovery with phenol after ammonium sulfate fractionation. Electrophoresis. 2007; 28 (14): 2358-2360.

PubMed Abstract | Publisher Full Text

42. Tan TK, Rijal P, Rahikainen $R$, et al.: A COVID-19 vaccine candidate using SpyCatcher multimerization of the SARS-CoV-2 spike protein receptor-binding domain induces potent neutralising antibody responses. 2020 . Publisher Full Text

43. Berndt A, Smalley T, Ren B, et al.: Recombinant production of a functional SARS-CoV-2 spike receptor binding domain in the green algae. Chlamydomonas Reinhardtii. 2021. Publisher Full Text
44. Wingfield $P$ : Protein precipitation using ammonium sulfate. Current protocols in protein science, Appendix 3., Appendix-3F. 2001 Publisher Full Text

45. Park S, Lim C, Kim D, et al.: Optimization of ammonium sulfate concentration for purification of colorectal cancer vaccine candidate recombinant protein GA733-fck isolated from plants. Front Plant Sci. 2015; 6.

PubMed Abstract | Publisher Full Text | Free Full Text

46. Tee KL, Jackson PJ, Scarrott JM, et al.: Purification of recombinant SARS-CoV-2 spike, its receptor binding domain, and CR3022 mab for serological assay. 2020.

Publisher Full Text

47. Keng CT, Zhang A, Shen S, et al.: Amino acids 1055 to 1192 in the S2 region of severe acute respiratory syndrome coronavirus $S$ protein induce neutralizing antibodies: implications for the development of vaccines and antiviral agents. J Virol. 2005; 79(6): 3289-3296.

PubMed Abstract | Publisher Full Text | Free Full Text

48. Batty CJ, Heise MT, Bachelder EM, et al.: Vaccine formulations in clinical development for the prevention of severe acute respiratory syndrome coronavirus 2 infection. Adv Drug Deliv Rev. 2021; 169: 168-189.

PubMed Abstract | Publisher Full Text | Free Full Text

49. Arbeitman CR, Auge G, Blaustein M, et al.: Structural and functional comparison of SARS-Cov-2-Spike receptor binding domain produced in Pichia pastoris and mammalian cells. 2020. Publisher Full Text

50. Layne E: $\mathbf{7 3}$ Spectrophotometric and turbidimetric methods for measuring proteins. Methods Enzymol. 1957: 447-454. Publisher Full Text

51. Stoscheck CM: 6 quantitation of protein. Methods Enzymol. 1990: 50-68. Publisher Full Text

52. Edwards RJ, Mansouri K, Stalls V, et al.: The receptor binding domain of SARS-CoV-2 spike protein is the result of an ancestra recombination between the bat-CoV RaTG13 and the pangolinCoV MP789. BMC Res Notes. 2020 Aug 27; 13(1): 398 PubMed Abstract | Publisher Full Text | Free Full Text

53. Dai L, Gao GF: Viral targets for vaccines against CoVID-19. Nat Rev Immunol. 2020; 21(2): 73-82.

PubMed Abstract | Publisher Full Text | Free Full Text

54. Dai L, Zheng $\mathrm{T}$, Xu K, et al.: A Universal Design of Betacoronavirus Vaccines against COVID-19, MERS, and SARS. Cell. 2020; 182(3) 722-733.e11.

PubMed Abstract | Publisher Full Text | Free Full Text

55. Othman $\mathrm{H}$, Bouslama Z, Brandenburg JT, et al.: Interaction of the spike protein RBD from SARS-CoV-2 with ACE-2: Similarity with SARS-CoV, hot-spot analysis and effect of the receptor polymorphism. Biochem Biophys Res Commun. 2020; 527(3): 702-708.

PubMed Abstract | Publisher Full Text | Free Full Text

56. Liu Z, Xu W, Xia S, et al.: RBD-fc-based COVID-19 vaccine candidate induces highly potent SARS-Cov-2 neutralizing antibody response. Signal Transduct Target Ther. 2020; 5(1). PubMed Abstract | Publisher Full Text | Free Full Text

57. Yang J, Wang W, Chen Z, et al.: A vaccine targeting the RBD of the $S$ protein of SARS-Cov-2 induces protective immunity. Nature 2020; 586(7830): 572-577.

PubMed Abstract | Publisher Full Text

58. Sewell HF, Agius RM, Stewart $\mathrm{M}$, et al.: Cellular immune responses to COVID-19. BMJ. 2020; m3018. PubMed Abstract | Publisher Full Text

59. Henderson R, Edwards RJ, Mansouri K, et al.: Glycans on the SARSCoV-2 Spike Control the Receptor Binding Domain Conformation. bioRxiv: the preprint server for biology. 2020 2020.06.26.173765.

Publisher Full Text 


\section{Open Peer Review}

\section{Current Peer Review Status: $\mathrm{X}$ ?}

\section{Version 1}

Reviewer Report 31 May 2022

https://doi.org/10.5256/f1000research.58248.r136859

(C) 2022 Nabi A. This is an open access peer review report distributed under the terms of the Creative Commons Attribution License, which permits unrestricted use, distribution, and reproduction in any medium, provided the original work is properly cited.

\section{A. H. M. Nurun Nabi}

Laboratory of Population Genetics, Department of Biochemistry and Molecular Biology, University of Dhaka, Dhaka, Bangladesh

1. The authors are proposing the use of purified RBD protein as a vaccine formulation. The question that arises here is why are you using the whole RBD protein instead of predicting the most antigenic epitopes and constructing a multi epitope vaccine.

Does their whole protein usage have any plus point over that?

2. In the introduction 'This suggests that the RBD residue is more conserved and hence, the RBD protein vaccines will be effective against multiple SARS-CoV-2 variants.' - this statement seems rather contradictory. RBD is a hot spot for mutations of the new variants. Kindly provide supporting references on behalf of your statement.

3. There have been several variants of SARS-CoV-2 with mutations in the RBD of the spike protein. Will this RBD vaccine be effective against all the variants? Furthermore, what is the significance of this study? The constructed RBD vaccine will serve as a subunit vaccine? Won't the RBD of the spike protein bind with ACE-2? It may serve as a competitive inhibitor.

4. Administration of this whole protein might induce the innate immune response by producing antibodies. The authors have mentioned in the discussion section "Other authors reported that a single dose of the RBD antigen vaccine delivered to mice has produced a high titer of antibodies effective against both mutant and non-mutant variants of the SARS-CoV-2 virus"

However, it is suggested that authors should perform some analysis that may demonstrate the immune simulation and represent the results to validate the probable effect of their designed vaccine.

5. Did the authors perform any allergen test for the vaccine?

6. The authors mentioned "Additionally, the RBD protein alone was found to have effective 
immunological integration with eight types of ACE-2 variants in human cells" in the discussion section. Although, a detailed population coverage analysis is recommended.

7. The protein was aligned and compared with the RBD protein generated by 2019- nCoV, SARS-CoV-2 virus (UniProtKB: P00750) only. What about the specific variants? Will the vaccine be effective against all possible variants?

8. It is suggested to write about any subunit or purified protein vaccine that was subjected to trial against SARS-CoV-2 or other viruses and their outcomes in the introduction.

The manuscript is well written. I have no comments regarding the proposed wet lab methodology. Although an extensive immunoinformatics based validation of their proposed outcome must be added in the projected results section. They are suggested to perform protein modeling and docking, in addition to immune simulation analysis to demonstrate the probable outcome of the vaccine. Thus I would suggest a major revision including these proposed analyses.

Is the rationale for, and objectives of, the study clearly described?

Partly

Is the study design appropriate for the research question?

Partly

Are sufficient details of the methods provided to allow replication by others? Partly

Are the datasets clearly presented in a useable and accessible format?

Not applicable

Competing Interests: No competing interests were disclosed.

Reviewer Expertise: Genetics, Immunoinformatics, Biochemistry

I confirm that I have read this submission and believe that I have an appropriate level of expertise to confirm that it is of an acceptable scientific standard, however I have significant reservations, as outlined above.

Author Response 10 Sep 2022

ZMG Sarwar Jahangir, Kingsborough Community College of The City University of New York, Brooklyn, USA

Dear Professor Dr. Nuran Nabi,

Thank you for reviewing our article and also for your questions, suggestions, and comments. Please find below specific answers in response to your peer review. In the revision, the text may remain modified to match the format of the article. We have included answers to all your questions in the $3^{\text {rd }}$ revised version of the article. 
Q1. "The authors propose using purified RBD protein as a vaccine formulation. The question that arises here is why are you using the whole RBD protein instead of predicting the most antigenic epitopes and constructing a multi-epitope vaccine.

Does their whole protein usage have any plus point over that?"

Answer: The entire RBD amino acid chain restores the integrity of the RBD epitope. Otherwise, the epitope may change its 3D structure. It has been demonstrated that an altered RBD amino acid chain elucidates phenotypic variation of the RBD protein. That allows the SARS-CoV-2 virus to escape binding to potently neutralizing anti-RBD antibodies which may relate to the altered epitopes (Deshpande, et al., 202139, Greaney, et al., 202144; Harvey, et al., $2021^{45}$ ). Hence, in this protocol, we will use the entire RBD coding sequence to preserve the epitope structure, instead of using the binding site alone.

Q2. "In the introduction 'This suggests that the RBD residue is more conserved and hence, the RBD protein vaccines will be effective against multiple SARS-CoV-2 variants.' - this statement seems rather contradictory. RBD is a hot spot for mutations of the new variants. Kindly provide supporting references on behalf of your statement."

Answer: The RBD residue carries the SARS-CoV-2 binding epitope that binds to the ACE- 2 receptors in human cells. However, recent findings of the RBD structure of mutant delta strain vary with omicron strain in their 3D structures, but both the variants can bind to the same ACE-2 receptors infecting patients (Kumar, et al., 2021) ${ }^{30}$. Hence, we assume the RBD sequence we have included in the protocol will be effective against multiple variants. Furthermore, the VH3-53/3-66 class-derived public neutralizing antibodies (NAbs) are effective against multiple SARS-CoV-2 variants (Xu et al, 2021) ${ }^{24}$. Hence, the RBD protein vaccine will be effective against multiple SARS-CoV-2 variants, without claiming it to be effective for all and forever. Once again, following the same protocol, the RBD DNA sequence is open for modification to match an altered variant if needed.

Q3. "There have been several variants of SARS-CoV-2 with mutations in the RBD of the spike protein. Will this RBD vaccine be effective against all the variants? Furthermore, what is the significance of this study? The constructed RBD vaccine will serve as a subunit vaccine? Won't the RBD of the spike protein bind with ACE-2? It may serve as a competitive inhibitor."

Answer 1: We gave a part of the answer to this question in the previous paragraph. The VH3-53/3-66 class-derived public neutralizing antibodies (NAbs) are effective against multiple SARS-CoV-2 variants (Xu et al, 2021) ${ }^{24}$. Hence, the RBD protein vaccine will be effective against multiple SARS-CoV-2 variants, without claiming it to be effective for all and forever. Furthermore, following the same protocol, the RBD DNA sequence is open for modification to match an altered variant if needed.

${ }^{24}$ Xu, H., Wang, B., Zhao, T., Liang, Z., Peng, T., Song, X., Wu, J., Wang, Y., \& Su, X. (2021). Structure-based analyses of neutralization antibodies interacting with naturally occurring SARS-Cov-2 RBD variants. Cell Research, 31(10), 1126-1129. https://doi.org/10.1038/s41422021-00554-1

Answer 2: The RBD vaccine has the following significance (Hernández-Bernal, et al. 202246, Mabrouk et al. 202147, Fliesle, N. 202148). 
1. Production of protein vaccine specific against SARS-CoV-2 without any potential for genomic recombination into the recipient's genome.

2. Production of the safer vaccine.

3. The RBD DNA will have the scope for alteration to produce new RBD matching the new SARS-COV-2 variants.

Answer 3: The RBD vaccine will work as a fully effective vaccine against the SARS-CoV-2 virus.

The amount of RBD molecules per vaccine will be limited and they will have no selfregenerating ability. Most of the titer will bind to $T$ cells and then instruct the $B$ cells to produce plasma cells for making antibodies against the SARS-CoV-2 virus. While the memory B cells will be involved in any future infection by the SARS-CoV-2. However, there will be limited opportunities for RBD vaccine molecules to bind the ACE- 2 receptors. This opportunity of the RBD protein vaccine is much less in comparison to the currently administered spike protein mRNA antigenic vaccine. The mRNA vaccine continuously produces spike protein for a prolonged period which also binds to the ACE-receptors as well (Angeli, et al., 2021) ${ }^{49}$. Hence, the RBD spike protein vaccine will have little competition in comparison to the spike protein produced by the mRNA vaccines.

Furthermore, spike proteins produced by the mRNA vaccine have an S2 segment that has the potential for facilitating fusion of the free-floating SARS-CoV-2, while the RBD protein vaccine has no potential for viral fusion into human cells (Belouzard, et al., 201250; Jackson, et al., $2022^{51}$ ). Hence, the RBD protein vaccine is safer.

Q4. "Administration of this whole protein might induce the innate immune response by producing antibodies. The authors have mentioned in the discussion section "Other authors reported that a single dose of the RBD antigen vaccine delivered to mice has produced a high titer of antibodies effective against both mutant and non-mutant variants of the SARS-CoV-2 virus"

However, it is suggested that authors should perform some analysis that may demonstrate the immune simulation and represent the results to validate the probable effect of their designed vaccine."

Answer: Following your suggestion, we included that "the purified RBD will be tested for immune simulations in 7 weeks old mice Female C57BL mice and tested for neutralizing antibodies produced against SARS-CoV-2 following as described by Seephetdee et al., (2021) 72 .

Q5. "Did the authors perform any allergen tests for the vaccine?"

Answer: We are not completing the allergen testing in this protocol. Once the RBD protein meets the immunity generation test, the authors will contact agencies interested in using it as a vaccine. At that time, after vaccine formulation following a standard protocol, it will go through allergen tests before application to patients following US FDA recommended vaccine evaluation and management protocol (Goepfert, et al., 202173; Greenhawt, et al., $2021^{74}$ )

Q6. "The authors mentioned "Additionally, the RBD protein alone was found to have effective 
immunological integration with eight types of ACE-2 variants in human cells" in the discussion section. Although, a detailed population coverage analysis is recommended."

Answer: Human ACE-2 variants are rare and mostly found in European non-Finnish and African populations except one in the Latino and one in finish populations, none in Ashkenazi Jewish, East and South Asian populations (Othman, et al., 2020) ${ }^{83}$. ${ }^{83}$ Othman $\mathrm{H}$, Bouslama Z, Brandenburg JT, et al.: Interaction of the spike protein RBD from SARS-CoV-2 with ACE-2: Similarity with SARS-CoV, hot-spot analysis and effect of the receptor polymorphism. Biochem Biophys Res Commun. 2020;527(3):702-708. 32410735 10.1016/j.bbrc.2020.05.028 PMC7221370

Q7. "The protein was aligned and compared with the RBD protein generated by 2019- $n$ CoV, SARS-CoV-2 virus (UniProtKB: P00750) only. What about the specific variants? Will the vaccine be effective against all possible variants?"

Answer: Yes, the RBD protein thus generated should be compared with other variants before vaccine formulation. Although there exist variations in the spike protein, variations in the RBD region are relatively limited.

When neutralization antibodies interact with naturally occurring SARS-CoV-2 RBD variants tested using structure-based analyses the VH3-53/3-66 class-derived public antibodies largely remain effective against most of the RBD variants studied (Xu, et al., 202124). The RBD variants lineages include the B.1.1.7 (UK) lineage that emerged in the United Kingdom (UK), the B.1.351 (South Africa-SA), and the P.1 and P.2 lineages in Brazil and others. The most abundant RBD variant mutations are N501Y in B.1.351, K417N (or T)/E484K/N501Y co-mutation in the SA and Brazil and are reported to be highly transmissible (Xu, et al., 202124).

Furthermore, the VH3-53/3-66 class-derived public neutralizing antibodies (NAbs) antibodies were the most prevalent NAbs identified in COVID-19 patients worldwide (Cao, et al., 202085 Yuan, et al., 202086).

Yes, the RBD protein will be still effective against more variants and justified in the review.

Q8. It is suggested to write about any subunit or purified protein vaccine that was subjected to trial against SARS-CoV-2 or other viruses and their outcomes in the introduction.

Answer: We included the following information in the 2 nd and $3^{\text {rd }}$ revisions. There are several reports on SARS-CoV-2 RBD and spike protein vaccines on trial (Formica, et al., 2021 40; Kyriakidis, et al., 202141).

Vaccinating across the globe against SARS-CoV-2 is a great scientific, logistical, and moral challenge. Manufacturing protein-based vaccines are potentially more cost-effective than mRNA vaccines and do not require ultra-cold storage ( Hernández-Bernal, et al. 202246, Mabrouk et al. 202147, Fliesle, N. 202148, Kleanthous, et al., 202138).

This would help with safe, potent, high-volume, and affordable vaccines for a large part of the world, especially in low- and middle-income countries, including Africa where vaccination rates are currently very low. Given a predominance of key biomarker neutralizing antibodies (NAbs) that target RBD following natural infection or vaccination, there is a great justification for selecting RBD as the sole vaccine immunogen. It has high- 
yielding potential, temperature-stable and cost-effective. In addition, the RBD focuses on the immune response to the potent and cross-protective domains which is central to the development of future pan-sarbecovirus vaccines (Kleanthous, et al., 202138). Kleanthous, et al., (2021) ${ }^{38}$ also reported that the RBD protein vaccines are equally effective in comparison to full-length S-protein vaccines concerning immune responses against the prototype pandemic SARS-CoV-2 isolate as well as emerging variants of concern.

In a clinical trial in CUBA, 792 subjects received the SARC-CoV-2 RBD protein vaccine named ABDALA on Dec 7, 2020, and Feb 9, 2021. The ABDALA vaccine was found to be safe, well tolerated, and induced humoral immune responses against SARS-CoV-2. For the emergency COVID-19 pandemic the results support a $50 \mu \mathrm{g}$ vaccine dose, applied in a 0-14-28 days schedule was highly effective. (Hernanadez-Bernal, et al., 2022 ${ }^{46}$ ).

A trial study was conducted on the efficacy and safety of a dimeric tandem repeat of RBD of the SARS-CoV-2 spike protein (derived from the Wuhan-Hu-1 strain) vaccine among a total of 28,873 participants conducted on December 12, 2020, and December 15, 2021, at 31 clinical centers across Uzbekistan, Indonesia, Pakistan, and Ecuador with a safety assessment center in China Dai, et al., (2022) ${ }^{42}$. In this large cohort of adults, the RBD dimeric vaccine was found to be safe and effective for at least 6 months after full vaccination against symptomatic as well as severe-to-critical Covid-19, without any vaccine-related death (Dai, et al., 2022) ${ }^{42}$.

Again, a SARS-CoV-2 recombinant spike protein nanoparticle vaccine in phase 1-2 trials where 83 participants received the vaccine with adjuvant, 25 received the vaccine without the adjuvant, and 23 participants received placebo, at random. At 35 days, the nanoparticle vaccine was found to be safe and elicited immune responses that exceeded levels in Covid19 convalescent serum (Keech, et al., 2020) ${ }^{43}$.

\section{Peer Reviewer's comments:}

"The manuscript is well written. I have no comments regarding the proposed wet lab methodology. Although an extensive immunoinformatics-based validation of their proposed outcome must be added in the projected results section. They are suggested to perform protein modeling and docking, in addition to immune simulation analysis to demonstrate the probable outcome of the vaccine. Thus, I would suggest a major revision including these proposed analyses."

Answer: Thank you very much for going through our manuscripts and making helpful comments and suggestions. We did our best to answer all your questions. We are looking forward if you have any other questions for us to answer.

Competing Interests: None. 
(C) 2022 Chen W. This is an open access peer review report distributed under the terms of the Creative Commons Attribution License, which permits unrestricted use, distribution, and reproduction in any medium, provided the original work is properly cited.

\section{Wen-Hsiang Chen}

Baylor College of Medicine, Houston, Texas, USA

In this manuscript, the authors described the procedure to produce a recombinant RBD protein as the COVID-19 vaccine antigen. This manuscript is relevant to the current COVID-19 pandemic. However, the overall design of the antigen, the procedure to purify the antigen, the characterization of purified RBD seemed to indicate that the procedure was not very efficient. This manuscript requires major improvement. The following comments are suggested:

\section{In the Abstract section:}

The advantage of mRNA/DNA vaccines is to avoid the production process of protein recombinantly, as recombinant protein production sometimes can be very challenging, considering each protein has unique biophysical characteristics which makes the expression/purification much more complex, versus for DNA or RNA vaccines, the purification process of DNA and RNA can typically remain very similar and straightforward. Thus, the background rationale addressing generating RBD protein as a fast-acting strategy may not make too much sense. Please consider re-write the rationale.

\section{In the Introduction section:}

The introduction section is extremely lengthy with disjointed information. Please consider removing unnecessary paragraphs and making them more concise.

Under "the benefits and importance of SARS-CoV-2 vaccines" section, the fourth paragraph: Authors stated that RBD residue is more conserved, however, based on the mutation maps of the current SARS-CoV-2 variants of concern (VoC; https://asm.org/Articles/2021/December/HowOminous-is-the-Omicron-Variant-B-1-1-529), one can find that all the VoCs contain mutations within the RBD region, the most recent VoC-Omicron even has 15 mutations. Thus, stating RBD is more conserved seems incorrect. Authors, please address accordingly.

Under "Advantages for using the RBD protein vaccine", the $2^{\text {nd }}$ paragraph: Authors listed several properties of RBD proteins, and stated that all these properties support the RBD protein as an effective antigen; one being the 4 cysteine bridges that RBD possesses. However, it is hard to correlate the effectiveness of this antigen with the Cys bridges. Could the authors clarify? Otherwise, please consider removing such info. Additionally, using RBD as the vaccine antigen against COVID-19 is not a new concept, and one can easily find articles describing similar ideas (e.g., Yang et al., Nature, 2020; Zhang et al., Cell Discov, 2021; Chen et al., BBA-Gen Subj. 2021; Dalvie, PNAS, 2021). This manuscript lacks the description of the advantages, the novelty, or a good rationale over the other published articles. Please consider providing reasons why your RBD design is better than the others to make your manuscript stronger.

\section{Comments on the overall design of the antigen:}


The authors designed an antigen that consists of the RBD protein, a linker (FP), and a GFP. However, it is unclear why GFP is required. Also, to remove the GFP, an additional enzyme had to be employed, which adds an extra step to the process and can potentially make it more difficult to purify. Authors should also beware that by using $E$. coli expression system, a complex protein such as RBD (containing many Cys bridges), may not have a correctly folded structure, as it can easily form an inclusion body instead of a soluble protein, which may explain why the overall yield was so low.

In the whole manuscript, no SDS-PAGE image was presented to demonstrate the expression of the protein actually occurred. The yield of the purified protein also seemed extremely low $(<10 \mathrm{pg} / \mathrm{mL}$ out of $1.5 \mathrm{~mL}$ cell culture) when quantified by BioVision ELISA kit. Authors should reconsider the production process, as this process did not seem efficient enough for protein production.

The authors used several in silico analyses to evaluate the structure of the expressed protein. But when the protein is expressed and purified, more sophisticated analyses should be performed. Minimally, a functionality test by evaluating the binding of RBD to ACE-2 should be considered. Additionally, for secondary structure analysis, circular dichroism can be used, and for Cys-bond formation, mass spectrometry should be considered.

Is the rationale for, and objectives of, the study clearly described?

Partly

Is the study design appropriate for the research question?

Partly

Are sufficient details of the methods provided to allow replication by others? Partly

Are the datasets clearly presented in a useable and accessible format? Partly

Competing Interests: No competing interests were disclosed.

Reviewer Expertise: Recombinant protein production. Vaccines. Protein biophysical characterization. Protein science

I confirm that I have read this submission and believe that I have an appropriate level of expertise to state that I do not consider it to be of an acceptable scientific standard, for reasons outlined above.

Author Response 16 Jan 2022

ZMG Sarwar Jahangir, Kingsborough Community College of The City University of New York, Brooklyn, USA

Professor Wen-Hsiang Chen,

Baylor College of Medicine, Houston, Texas, USA 
Dear Professor Chen:

Thank you for reviewing our submission to F1000, "A study protocol to prepare an RBD protein for vaccine against COVID-19", and for your suggestions. We will address all issues you suggested to enrich the article. However, we will wait to get responses from two additional reviewers before we make the revision.

Yours truly.

ZMG Sarwar Jahangir, Ph.D. Molecular, Cellular and Developmental Biology and Director, AS in Biotechnology Program, Department of Biological Sciences KCC-CUNY and Arleta H. Marnik, M.S. in Biotechnology, GDANSK University of Technology, Poland, Research Scientist, Department of Biological Sciences, KCC-CUNY.

Competing Interests: We the authors have no competing interest with the reviewer influencing judgments.

The benefits of publishing with F1000Research:

- Your article is published within days, with no editorial bias

- You can publish traditional articles, null/negative results, case reports, data notes and more

- The peer review process is transparent and collaborative

- Your article is indexed in PubMed after passing peer review

- Dedicated customer support at every stage

For pre-submission enquiries, contact research@f1000.com 